WAPD-TM-213

AEC RESEARCH AND DEVELOPMENT REPORT

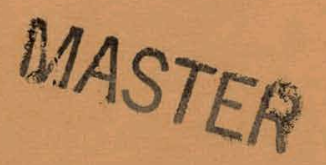

STDY-3, A PROGRAM FOR THE THERMAL ANALYSIS OF A PRESSURIZED WATER NUCLEAR REACTOR DURING STEADY-STATE OPERATION

JUNE 1960

CONTRACT AT-11-1-GEN-14

BETTIS ATOMIC POWER LABORATORY, PITTSBURGH, PA., OPERATED FOR THE U.S. ATOMIC ENERGY COMMISSION BY WESTINGHOUSE ELECTRIC CORPORATION 


\section{DISCLAIMER}

This report was prepared as an account of work sponsored by an agency of the United States Government. Neither the United States Government nor any agency Thereof, nor any of their employees, makes any warranty, express or implied, or assumes any legal liability or responsibility for the accuracy, completeness, or usefulness of any information, apparatus, product, or process disclosed, or represents that its use would not infringe privately owned rights. Reference herein to any specific commercial product, process, or service by trade name, trademark, manufacturer, or otherwise does not necessarily constitute or imply its endorsement, recommendation, or favoring by the United States Government or any agency thereof. The views and opinions of authors expressed herein do not necessarily state or reflect those of the United States Government or any agency thereof. 


\section{DISCLAIMER}

Portions of this document may be illegible in electronic image products. Images are produced from the best available original document. 
UC-34: Physics and Mathematics TID-4500 (15th Ed.)

\title{
STDY-3, A PROGRAM FOR THE THERMAL ANALYSIS OF A PRESSURIZED WATER NUCLEAR REACTOR DURING STEADY-STATE OPERATION
}

R. S: Pyle

JUNE 1960

Contract AT-11-1-GEN-14

\begin{abstract}
Price $\$ \mathbf{1 . 0 0}$
Available from the office of Technical Services,

Department of Commerce,

Washington 25, D. C.
\end{abstract}

NOTE

This document is an interim memorandum prepared primarily for internal reference and does not represent a final expression of the opinion of Westinghouse. When this memorandum is distributed externally, it is with the express understanding that Westinghouse makes no representation as to completeness, accuracy, or usability of informution contained thereln.

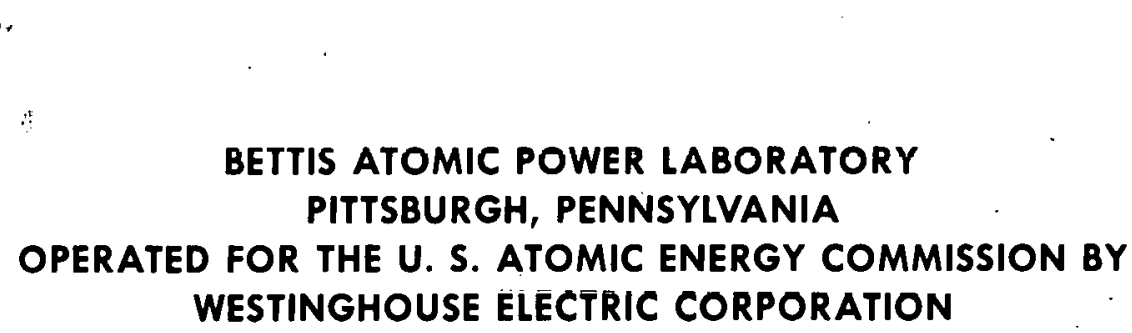


UC-34: Physics and Mathematics, TID-4500, 15th Edition

No. Coples

\section{SPECIAL EXTERNAL DISTRIBUTION}

Manager, Pittsburgh Naval Reactors Operations Office, AEC

Director, Development Division, PNROO
3
Total $\quad \begin{array}{r}3 \\ \hline 617\end{array}$

This report was prepared as an account of Government sponsored work. Neither the United states, nor the lommission, nor any person acting on behalt of the Commission:

A. Makes any warranty or representation, expressed or implied, with respect to tho accuracy, completeness, or usefulness of the information contained in this report, or that the use of any information, apparatus, method, or process disclosed in this report may not infringe privately owned rights; or

B. Assumes any liabilities with respect to the use of, or for damages resulting from the use of any information, apparatus, method, or process disclosed in this report.

As used in the above, "person acting on behalf of the Commission" includes any employe or contractor of the commission, or employe of such contractor, to the extent that such employe or contractor of the Commission, or employe of such contractor prepares, disseminates, or provides access to, any information pursuant to his employment or contract with the Commission, or his employment with such contractor. 


\section{CONTENTS}

Page No.

\section{INTRODUCTION}

II. PROGRAMMED EQUATIONS

A. Enthalpy Rise in an Axial Increment $\Delta \mathrm{Z}$, 2

B. Quality and Specific Volume $\quad$.

C. Pressure Drop $\quad$ · . . . 3

D. Criteria for the Existence of Local Boiling (Pressure Drop Only) 4

E. Hot Channel Pressure Drop and Plenum Factor

F. Metal Surface Temperature $\left(T_{s}\right)$, Metal Temperature $\left(T_{m}\right)$, Departure from Nucleate Boiling Ratio (DNBR)

G. High Pressure $\geq 1850$ Psia) Heating and Local Boiling . 8

H. Low Pressure (< 1850 Psia) Heating 8

I. Low Pressure Local Boiling $\quad$. 8

J. High Pressure (> 1850 Psia) Bulk Boiling 8

' Basic Equations, Limited to $\mathrm{G} \geq 0.7 \times 10^{6}$ and $\mathrm{X} \leq 0.4 \quad 8$ $\begin{array}{ll}\text { Extrapolation Equations } & 8\end{array}$

K. Low Pressure (< 1850 Psia) Bulk Boiling $\quad$. 9

L. Second-Pass Inlet Conditions 9

III. INPUT-OUTPUT OPTIONS . 10

IV. INPUT FORM PREPARATION 11

A. STDY Input Form (Page 1) 11

Title Card $\quad 11$

Control Card $\quad$. 12

$\begin{array}{ll}\text { Pressure Card } & 13\end{array}$

Flow Card (Card 4) 13

Flow Card (Card 5) $\quad 13$

$\begin{array}{ll}\mathrm{I}_{\text {in }} \text { Card } & 1.3\end{array}$

$\emptyset_{\text {ave }}$ Card $\quad \cdots$

B. STDY Input Form (Page 2) $\quad 13$

Channel Description Cards $\quad$. 13

Plenum Cards $\quad 14$

Axial Flux Weighting Cards $\quad 14$

V. ESTIMATED RUNNING̈ TIME

VI. SAMPLE INPUT AND OUTPUT $\quad$.

VII. MACHINE OPERATING INSTRUCTIONS

ACKNOWLEDGEMENTS 
Page No.

REFERENCES

16

APPENDIX I: STDY INPUT FORMS

APPENDIX II: SAMPLE PROBLEM

APPENDIX III: WATER PROPERTY CURVE FITS

25

APPENDIX IV: PRESSURE DROP AND VOID FRACTION CORRELATION CURVE FITS

37 


\begin{abstract}
A digital program to perform a steady-state, parallel channel thermal analysis of a rectangular water channel nuclear reactor, with a plate-type fuel element is described. Feotures that automatically vary certain input values to aid in parametric studies are included. The program was assembled by the FORTRAN compiler for - 16,000 word IBM.704 computer, including three tape units and one logical drum.
\end{abstract}

\title{
STDY-3, A PROGRAM FOR THE THERMAL ANALYSIS OF A PRESSURIZED \\ WATER NUCLEAR REACTOR DURING STEADY-STATE OPERATION
}

\section{R. S. Pyle}

\section{INTRODUCTION}

The digital code described herein was programmed for the IBM-704 computer with the aid of the FORTRAN compiler. This code is a composite of the best features of all the previous Bettis steady-state analysis codes. The present version is 1dentified as STDY-3 and has been in general production since July 1, 1959.

STDY-3 performs a complete steady-state, parallel channel thermal analysis of a rectangular water channel core with a plate-type fuel element. The digital code performs enthalpy and temperature rise calculations for the core average channel from input parameters. Two-phase core pressure drop calculations are performed using the latest equations as described in Section II (Programmed Equations). These calculations include the pressure drop effects of acceleration, elevation, friction, and entrance and exit.

Hot channel pressure drop is computed by modifying the normal channel pressure drop by an input controlled plenum equation. To accurately compute the hot channel flow where the flow vs pressure drop curve may contain inflections, a table of hot channel flow vs pressure drop is constructed by a stepwise reduction of flow from $100 \%$ (times some optional input multiplier) of the average channel value to a flow producing excess steam quality $(>100 \%)$ in the hot channel. The flow vs pressure drop table is then searched and interpolated for a pressure drop value within two percent of the hot channel pressure drop as determined by the plenum effects on the normal channel. The flow corresponding to this pressure drop is considered the hot channel flow. Once the hot channel flow is determined, enthalpy, temperature, and steam quality values are printed. Maximum metal surface temperature, meat centerline temperature, and DNB ratio calculations are made for each axial point from input properties and design equations.

The program is capable of solving steady-state problems, including one and two pass cores, up to two liut chamels per pass, and the parameter variations necessary for core safety margin calculations. For 
safety margin calculations, up to five values each of system pressure, flow, inlet temperature, and power may be supplied for the same core. Each parameter is varied Independently through the set of values supplied, and then returned to its original value while another parameter is varied.

\section{PROGRAMMED EQUATIONS}

A. Enthalpy Rise in an Axial Increment $\Delta \mathrm{Z}$

$$
\Delta H_{j}=\left(\frac{\emptyset_{\text {ave }} F \emptyset_{\text {ave }} f^{\prime}(z)_{j}}{G}\right)\left(\frac{A_{H}}{A_{f}}\right),
$$

where.

$\emptyset_{\text {ave }}$ is the average heat flux in the channel $\left(\mathrm{Btu} / \mathrm{hr}-\mathrm{ft}^{2}\right)$,

$F \emptyset_{\text {ave }}$ is the average engineering hot channel factor (Includes fuel density, thickness, and eccentricity), usually 1.0 for the average ohannel,

$f^{\prime}(z)_{j}$ is the ratio of the average heat flux at the $j_{\text {th }}$ elevation to the average heat flux in the channel,

$\mathrm{G}$ is the mass velocity in the channel $\left(\mathrm{lb} / \mathrm{hr}-\mathrm{ft}^{2}\right)$,

$A_{h} / A_{f}$ is the ratio of the effective heat transfer area to the effective flow area for the increment $\Delta \mathrm{Z}$ (program assumes area widths are equal and $A_{h} / A_{f}=2 \Delta Z /$ channel thickness).

B. Quality and Spectfic Volume

$$
x_{j}=\frac{H_{j}-H_{\text {sat }}}{H_{f g}}
$$

where

$\mathrm{H}_{\mathrm{j}}$ is the average enthalpy at the $\mathrm{j}_{\text {th }}$ elevation,

$\mathrm{H}_{\text {sat }}, \mathrm{H}_{\mathrm{fg}}$ are the fluid physical properties (see Appendix III).

$$
\begin{array}{r}
v_{i}=\frac{1}{R_{j}}=v_{f}+X_{j} v_{f g} \text { (homogenous model) } \\
v_{j}=\frac{1}{\rho_{j}}=\frac{1}{R_{g} \rho_{g}+\left(1-R_{g}\right) \rho_{f}} \text { (slip finw model) }
\end{array}
$$

where

$\rho_{\mathrm{j}}$ is the fluid density $\left(\mathrm{lb} / \mathrm{ft}^{3}\right)$,

$v_{f}, f_{f g}, \rho_{g}, \rho_{f}$ are the fluid physical properties (See Appendix III),

$R_{g}$ is the Martinelli void fraction (See Appendix IV). 
C. Pressure Drop

$$
\begin{aligned}
\Delta \mathrm{P} \text { Total }=\Delta \mathrm{P}_{\text {acceleration (1) }}+\Delta \mathrm{P}_{\text {acceleration (2) }}+\Delta \mathrm{P}_{\text {elevation }} \\
+\Delta \mathrm{P}_{\text {friction }}+\Delta \mathrm{P}_{\text {entrance and exit, }}
\end{aligned}
$$

where

$$
\begin{aligned}
& \Delta \mathrm{P}_{\mathrm{acc}(1)}=\frac{\mathrm{G}^{2}}{\mathrm{~g}_{\mathrm{c}}}(\mathrm{SPT} 1-\mathrm{SPT} 2), \quad \text { (spacial) } \\
& \Delta \mathrm{P}_{\text {acc (2) }}=\frac{\mathrm{G}^{2}}{2 \mathrm{~g}_{\mathrm{c}}} \quad\left[\left(\frac{\sigma_{\text {out }}^{2}-1}{\rho_{\text {out }}}\right)-\left(\frac{\sigma_{\text {in }}^{2}-1}{\rho_{\text {in }}}\right)\right] \text { (configuration change) }, \\
& \Delta P_{\text {elev }}=\sum_{j=1}^{j=j_{b b}} \rho_{j} \Delta z+\sum_{j=j_{b b}}^{j=k} \frac{1}{v_{j}} \Delta z, \\
& \Delta P_{\text {fric }}=\frac{G^{2}}{2 g_{c} D_{e}} \sum_{j=1}^{j=j_{b b}}\left(\frac{f / f_{\text {iso }}}{\rho}\right)_{j} f_{\text {iso }_{j}} \Delta Z \\
& \left.+\frac{G^{2}}{2 g_{c} D_{e}} \sum_{j=j_{b b}}^{j=k} \Phi_{L O}^{2} \text { (fiso, sat }\right)_{j} \Delta z \\
& \Delta P_{E \& E}=\frac{G^{2}}{2 g_{c}}\left(\frac{K_{c}}{\rho_{\text {in }}}+\frac{K_{e}}{\rho_{\text {out }}}\right)
\end{aligned}
$$

and where

$\mathrm{G}$ is the mass velocity in the channel $\mathrm{ab} / \mathrm{hr}^{-\mathrm{ft}^{2}}{ }^{2}$,

$\mathrm{g}_{\mathrm{c}}$ is the acceleration of gravity $\left(32.2 \mathrm{ft} / \mathrm{sec}^{2}\right)$,

$\rho_{\text {in }}, \rho_{\text {out }}$ is the density of fluid in or out of the channel $\left(\mathrm{lb} / \mathrm{ft}^{3}\right), *$

$\rho_{j}$ is the average density of fluid in section $j$,*

$\nabla_{j}$ is the average specific volume of fluid in section $j, * *$

$\nabla_{\mathrm{f}}$ is the fluid speclfic volume at saturation temperature,

$\Delta \mathrm{Z}$ is the axial increment length (ft),

*Hómogenous density or specific volume model always.

**Homogenous or slip flow spectfic volume model depending on pressure: (homogenous $\geq 1850$ psia; slip <1850 psia). 
$j$ is the specific axial increment,

$\mathrm{k}$ Is the total number of axial increments,

$\jmath_{\mathrm{bb}}$ is the increment number where bulk boiling begins,

$K_{c}, K_{e}$ is the unrecoverable entrance or exit coefficient,

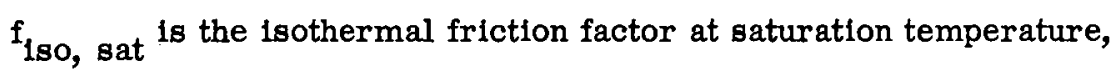

$\sigma_{\text {in' }}, \sigma_{\text {out }}$ is the area ratio at entrance or exit (ratio of the smaller to larger area),

De is the channel hydraulic diameter ( $2 \times$ channel thlckness),

$f_{\text {iso }}$ is the isothermal friction factor from an equation of the type

$$
f_{\operatorname{lgn}}=\frac{a}{\operatorname{Re}^{b}}
$$

$f / f_{\text {iso }}$ is the friction factor ratio for heating and local bolling,

$\Phi_{L O}^{2}$ is the ratio of two-phase frictional pressure drop grudient to corresponding isothermal liquid gradlent,

$\left.\begin{array}{ll}\text { SPT1 } & 1 / \rho_{\text {out }} \\ \text { SPT2 } & 1 / \rho_{\text {in }}\end{array}\right\}$

(subcooled channel)

SPT1,SPT2 $=\nabla_{f}+X_{\text {out, in }} \nabla_{f g}\left(\right.$ bolling $\left.<_{\text {entrance }}\right)(\geq 1850$ psia $)$

$$
=\frac{\left(1-\mathrm{X}_{\text {out, in }}\right)^{2} \mathrm{v}_{\mathrm{f}}}{1-\mathrm{R}_{\mathrm{g}}}+\frac{(\mathrm{X} \text { out,in })^{2} \mathrm{v} g}{\mathrm{R}_{\mathrm{g}}}\left(\text { boiling }{ }_{\text {entrance }}^{\text {exit }}\right)(<1830 \mathrm{psia}) \text {. }
$$

D. Ciriteria for the Existence of Local Bolling (Pressure Drop Only)

A channel is considered to be local bolling when

$$
\theta_{\mathrm{f}} \geq{ }^{\theta} \mathrm{J} \& \mathrm{~L}
$$

where

$$
\begin{aligned}
& \theta_{f}=\frac{\emptyset_{\text {ave }} F \emptyset_{\text {ave }} f^{\prime}(z)}{h}, \\
& \theta_{J \& L}=T_{\text {sat }}+\frac{60\left(\frac{\emptyset_{\text {ave }} F \phi_{\text {ave }} f^{\prime}(z)}{10^{6}}\right)^{1 / 4}}{e^{P / 900}}-T_{j}, \\
& h=H C O\left(\frac{k}{D e}\right) \operatorname{Re}^{0.8} \operatorname{Pr}^{0.4} \text { (see Appendix IV), }
\end{aligned}
$$




$$
\begin{aligned}
\mathrm{HCO} & =0.023 \text { at }<1850 \text { psia (design) } \\
& =0.030 \text { at } \geq 1850 \text { psia (design) } \\
& =0.030 \text { at all pressures (best fit) }
\end{aligned}
$$

$T_{\text {sat }}$ is the saturation temperature,

$T_{j}$ is the fluid temperature in section $j$,

$P$ is the system pressure (psia).

Local boiling is not considered for pressure drop purposes if it exists based on local factors only.

\section{E. Hot Channel Pressure Drop and Plenum Factor}

It is customary in parallel channel analysis to equate the pressure drop across channels in order to determine the distribution of flow. It is recognized that this may lead to some error if a point of exactly uniform static pressure common to all parallel channels is not chosen as a reference both up and down stream from the parallel channels. Thus, the inlet to outlet pressure drop of one channel may not equal the inlet to outlet pressure drop of another channel. This situation is generally referred to as "plenum maldistribution" and traditionally gives rise to a plenum hot channel factor:

$$
(\mathrm{F} \Delta \mathrm{T})_{\mathrm{P}}=\frac{\text { average channel flow }}{\text { hot channel flow }}
$$

This hot channel factor concept is obviously unsatisfactory since a reactor operates in the local and bulk bolling regions and the hot channel factor exists because of a difference in channel pressure drops; hence, the flow distribution is dependent upon the particular friction factors present. The friction factors may vary considerably as the amount of bulk and/or local bolling changes. Therefore, to account for the "plenum maldistribution," STDY-3 treats it as a reduction in the pressure drop across the hot channel.

STDY-3 uses a very general plenum equation to predict hot channel pressure drop. By the various algebraic manipulations illustrated below, this equation can be made to conform to most of the accepted methods of calculating hot channel pressure drop.

The general plenum equation programmed is:

$$
\begin{aligned}
\Delta \mathrm{P}_{\mathrm{HC}}=\mathrm{K}_{1} \mathrm{~K}_{2}\left(\Delta \mathrm{P}_{\mathrm{AC}}\right)_{\text {total }}+\left(1-\mathrm{K}_{1} \mathrm{~K}_{2}\right)\left(\Delta \mathrm{P}_{\mathrm{AC}}\right) \text { elevation } \\
\quad+\left[\mathrm{K}_{1} \mathrm{~K}_{1}^{\prime} \mathrm{K}_{2}^{\prime}+\mathrm{K}_{2} \mathrm{~K}_{1}^{\prime}-\mathrm{K}_{1} \mathrm{~K}_{2}\left(1+\mathrm{K}_{1}^{\prime}\right)\right]\left(\Delta \mathrm{P}_{\mathrm{AC}}\right)_{\text {acceleration }},
\end{aligned}
$$

where

$$
\begin{aligned}
\left(\Delta \mathrm{P}_{\mathrm{AC}}\right)_{\text {total }} & =\left(\Delta \mathrm{P}_{\mathrm{AC}}\right)_{\text {acceleration }}+\left(\Delta \mathrm{P}_{\mathrm{AC}}\right)_{\text {friction }} \\
& +\left(\Delta \mathrm{P}_{\mathrm{AC}}\right)_{\text {elevation }}+\left(\Delta \mathrm{P}_{\mathrm{AC}}\right)_{\text {entrance }}+\text { exit }
\end{aligned}
$$

and where $K_{1}, K_{2}, K_{1}^{\prime}, K_{2}^{\prime}$ are input plenum factors. 
By substitutions in the above equation, the following additional forms are possible:

$$
\begin{aligned}
& \text { If } \mathrm{K}_{1}^{\prime}=\mathrm{K}_{1} \text { and } \mathrm{K}_{2}^{\prime}=\mathrm{K}_{2}=1.0 \text {, } \\
& \Delta \mathrm{P}_{\mathrm{HC}}=\mathrm{K}_{1}\left(\Delta \mathrm{P}_{\mathrm{AC}}\right)_{\text {total }}+\left(1-\mathrm{K}_{1}\right)\left(\Delta \mathrm{P}_{\mathrm{AC}}\right)_{\text {elevation }} \\
& \text { - - - - - - - - - - - - - - - - - - } \\
& \text { If } K_{1}^{\prime}=K_{2}^{\prime}=1.0 \text {, } \\
& \Delta \mathrm{P}_{\mathrm{HC}}=\mathrm{K}_{1}\left(\Delta \mathrm{P}_{\mathrm{AC}}\right)_{\text {total }}+\left(1-\mathrm{K}_{1}\right)\left(\Delta \mathrm{P}_{\mathrm{AC}}\right)_{\text {elevation }}+\left(1-\mathrm{K}_{1}\right)\left(\Delta \mathrm{P}_{\mathrm{AC}}\right)_{\text {acceleration }} \\
& \text { - - - - - - - - - - - - - - - - - - - - - } \\
& \text { If } \mathrm{K}_{2}=\mathrm{K}_{2}^{\prime}=1.0 \text {, } \\
& \Delta P_{H C}=K_{1}\left(\Delta P_{A C}\right)_{t o t a l}+\left(1-K_{1}\right)\left(\Delta P_{\Lambda C}\right)^{\prime} \text { elevation }+\left(K_{1}^{\prime}-K_{1}\right)\left(\Delta P_{A C}\right)_{\text {acceleration }}
\end{aligned}
$$

This form is identical to the ART form (Ref 1) as follows: Let $\mathrm{K}_{1}=\mathrm{K}_{\mathrm{p1}}^{\mathrm{HC}}$ and $\mathrm{K}_{1}^{\prime}=\mathrm{K}_{\mathrm{pa}}^{\mathrm{HC}}$; then

$$
(\Delta \mathrm{P})^{\mathrm{HC}}=\mathrm{K}_{\mathrm{pf}}^{\mathrm{HC}}\left(\Delta \mathrm{P}_{\mathrm{f}}\right)^{\mathrm{NC}}+\mathrm{K}_{\mathrm{pa}}^{\mathrm{HC}}\left(\Delta \mathrm{P}_{\mathrm{a} 2}\right)^{\mathrm{NC}}+\left(\Delta \mathrm{P}_{\mathrm{el}}\right)^{\mathrm{NC}}
$$

F. Metal Surface Temperature $\left(T_{s}\right)$, Metal Temperature $\left(T_{m}\right)$, Departure from Nucleate Boiling Ratio (DNBR)

$$
T_{\mathbf{s}}=T_{j}+\theta_{10 c}^{*}
$$

where

$$
\begin{aligned}
& \theta_{\mathrm{loc}}^{*}=\theta_{\mathrm{f}_{\mathrm{l} \mathrm{O}}} \text { if } \theta_{\mathrm{f}_{\mathrm{loO}}}<\theta_{\mathrm{J} \& \mathrm{~L}_{\mathrm{loc}},} \\
& { }^{*}{ }_{\mathrm{loc}}=\theta_{\mathrm{J} \& \mathrm{~L}_{\mathrm{loc}}} \text { if } \dot{\theta}_{\mathrm{f}_{\mathrm{loc}}}>\theta_{\mathrm{J} \& \mathrm{~L}_{\mathrm{loc}},}
\end{aligned}
$$

$\dot{\theta}_{\mathrm{f}_{\mathrm{loc}}}$ and $\theta_{\mathrm{J} \& \mathrm{~L}_{\mathrm{loc}}}$ are defined in the local boiling section, except $\mathrm{F} \emptyset_{\mathrm{loc}}$ replaces $\mathrm{F} \emptyset_{\text {ave }}$ and

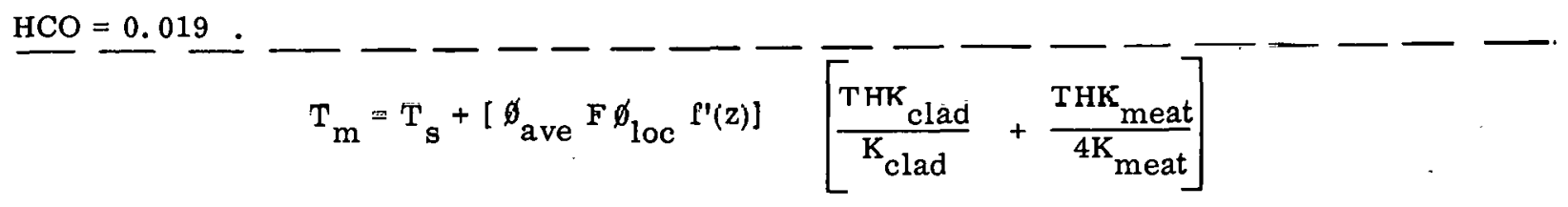

where

$\mathrm{THK}_{\text {clad }}, \mathrm{THK}_{\text {meat }}=$ clad and meat thickness

$\mathrm{K}_{\text {clad }}, \mathrm{K}_{\text {meat }}=$ clad and meat conductivity 
The five DNB equations are presently programmed Into STDY-3; the particular equation used is controlled by the equation cholce number, the $\mathrm{f}$ section enthalpy, the channel flow, and the system pressure.

$$
\begin{aligned}
& \mathrm{DNB}_{1}=\operatorname{BOCN1}\left(\frac{\mathrm{H}_{\mathrm{j}}}{1000}\right)^{-2.5} \mathrm{e}^{-0.0012 \mathrm{~L} / \mathrm{S}}\left(\mathrm{F}_{\mathrm{p}}\right) \\
& \mathrm{DNB}_{2}=\operatorname{BOCN} 2\left(\frac{\mathrm{H}_{\mathrm{j}}}{1000}\right)^{-2.5} \cdot \mathrm{e}^{-0.0012 \mathrm{~L} / \mathrm{S}}\left(1+\frac{\mathrm{G}_{\mathrm{loc}}}{10^{7}}\right)^{2} \\
& \mathrm{DNB}_{3}=\operatorname{BOCN} 3\left(\frac{\mathrm{H}_{\mathrm{j}}}{1000}\right)^{-0.72} e^{-0.0012 \mathrm{~L} / \mathrm{S}} \\
& \mathrm{DNB}_{4}=\left(0.37 \times 10^{6}\right)\left(\frac{\mathrm{H}_{\mathrm{j}}}{1000}\right)^{-(2.1+0.065 \mathrm{~L})} \mathrm{e}^{-0.03 \mathrm{~L}} \\
& \mathrm{DNB}_{5}=\left(0.76 \times 10^{6}\right)\left(\frac{\mathrm{H}_{\mathrm{J}}}{1000}\right) 0.497-0.0962 \mathrm{~L} e^{-0.0384 \mathrm{~L}}
\end{aligned}
$$

\begin{tabular}{|c|c|c|c|c|c|c|c|c|c|c|}
\hline & & . & & DNB & quat & ion & & & $\begin{array}{l}\text { Equ } \\
\mathrm{Ch}\end{array}$ & ion \\
\hline $\begin{array}{c}\text { Eq } \\
\text { Choice }\end{array}$ & $\begin{array}{l}\text { System } \\
\text { Pressure }\end{array}$ & Range & 1 & 2 & 3 & 4 & 5 & $\times 10^{5} \downarrow$ & 1 & 2 \\
\hline 1 & $\begin{array}{c}\mathrm{HP} \\
\geq 1850 \mathrm{psia}\end{array}$ & $\begin{array}{l}\mathrm{G}_{10 \mathrm{l}} \leq \\
1.6 \times 10^{6}\end{array}$ & $\mathrm{X}$ & & & & & BOCN1 & 3.25 & 5.0 \\
\hline & & $\begin{array}{l}G_{1 o c}> \\
1.6 \times 10^{6}\end{array}$ & & $\mathrm{X}$ & & & & & & \\
\hline$?$ & LP & - & & $\min$ & & & & BOCN2 & 2.40 & 3.7 \\
\hline & $<1850 \mathrm{psia}$ & & & value & & & & BOCN3 & 8.90 & 14.0 \\
\hline & $\begin{array}{c}\text { HP } \\
\geq 1850 \mathrm{psia}\end{array}$ & -- & & & & $\mathrm{X}$ & & $\begin{array}{l}\mathrm{F}_{\mathrm{p}}=1.0 \\
\text { to } 800 \mathrm{p}\end{array}$ & at 185 & -2000 \\
\hline & $\begin{array}{c}\text { LP } \\
<1850 \text { psia }\end{array}$ & -- & & & & & $\mathrm{X}$ & $\begin{array}{l}F_{p}=1.2 \\
\text { (1) inear }\end{array}$ & $\begin{array}{l}\text { at } 12 C \\
\text { twee }\end{array}$ & psia \\
\hline
\end{tabular}

where $L$ is the distance from the channel entrance to the center of the $J_{\text {th }}$ section and $S$ is the channel thickness.

The following chart illustrates the DNB equation used for each combination of problem parameters.

The hot channel DNB ratio is calculated using one of the five DNB equations and the following:

$$
\text { DNBR }=\frac{\text { DNB }_{x}}{\emptyset_{\text {ave }} F \emptyset_{\text {loc }} f^{\prime}(z)} .
$$


G. High Pressure ( $\geq 1850$ Psia) Heating and Local Bolling

$$
f / f_{\text {iso }}=C_{1}\left\{1+\left[\operatorname{PD2}\left(\frac{3500-P}{1500}\right)\left(\frac{10^{6}}{G}\right)^{2 / 3} \Psi\right]\right\} \text {, }
$$

where

$$
\begin{aligned}
\mathrm{C}_{1} & =\operatorname{PD} 1\left(1-0.0025 \theta^{*}\right) . \mathrm{C}_{1} \text { must be }<1.0 \text { or } \mathrm{C}_{1} \text { is set to } 1.0 ., \\
\Psi & =1-\left(\theta^{*} / \theta_{\mathrm{f}}\right), \\
\operatorname{PD} 1 & =1.05 \text { (design) } \\
& =1.00 \text { (best fit), } \\
\operatorname{PD2} & =0.912 \text { (design) } \\
& =0.16 \text { (besit tit). }
\end{aligned}
$$

H. Low Pressure (<1850 Psia) HeutIng

$$
\begin{aligned}
f / f_{\text {iso }} & =1.0(\text { design }) \\
& =1.0-0.001304 \theta_{f} \text { (best fit) }
\end{aligned}
$$

I. Low Pressure Local Boiling

$$
f / f_{\text {iso }}=1+\frac{T_{\text {ave }}-T_{\text {lb }}^{*}}{T_{\text {sat }-T_{\text {lb }}^{*}}^{*}} \quad\left[\left(f / f_{\text {iso, sat }}\right)-1\right]
$$

where

$$
\begin{aligned}
& \mathrm{T}_{\mathrm{lb}}^{*}=\mathrm{T}_{\text {aat }}+\frac{60\left(\emptyset / 10^{6}\right)^{0.25}}{e^{\mathrm{P} / 000}}-\frac{\phi}{\mathrm{h}} \\
& \mathrm{f} / \mathrm{f}_{\text {iso, sat }}=\text { Martinelli value for } \Phi_{\text {LO }}^{2} \text { at } 4.2 \% \text { quality . }
\end{aligned}
$$

J. High Pressure ( $\geq 1850$ Psla) Bulk Boiling

$\underline{\text { Basic Equations, Limited to } \mathrm{G} \geq 0.7 \times 10^{6} \text { and } \mathrm{X} \leq 0.4}$

$$
\begin{gathered}
\Phi_{\mathrm{LO}}^{2}-(A B O)(F \wedge M) \quad 0 \leq X<0.02 \\
\Phi_{\mathrm{LO}}^{2}=(\mathrm{ABC})(\mathrm{FAM})\left(\frac{\mathrm{FMN} \text { at } \mathrm{P}}{\mathrm{FMN} \text { at } 2000 \mathrm{psia}}\right) 0.02 \leq \mathrm{X} \leq 0.04
\end{gathered}
$$

$\underline{\text { Extrapolation Equations }}$

$$
\begin{gathered}
\Phi_{\text {LO }}^{2}=\Phi_{\text {LO }}^{2}\left(\frac{\text { FAM at X }=0.4}{\text { FAM }}\right)\left(\frac{\text { FMN at P }}{4.75}\right) 0.4<X \leq 1.0 \\
\Phi_{\text {LO }}^{2}=\Phi_{\text {LO }}^{2}\left(\frac{\text { FAM at } G=0.7 \times 10^{6}}{\text { FAM }}\right)\left[1+0.93\left(0.7-\frac{G}{10^{6}}\right)\right] \text { G }<0.7 \times 10^{6}
\end{gathered}
$$


where

FAM is the family of curves representing $\Phi_{\text {LO }}^{2}$ bulk boiling pressure drop data at 2000 psia. (Appendix IV) (see Ref 2),

FMN are the Martinelli values of $\Phi \underset{\text { LO }}{2}$ for bulk bolling pressure drop (Appendix IV) (see Ref 3),

$\mathrm{ABC}=1.1$ design

$=1.0$ best fit.

If $\Phi_{\text {LO }}^{2}<1$ in the above equations, $\Phi_{\text {LO }}^{2}$ is set equal to one.

K. Low Pressure (<1850 Psia) Bulk Boiling

For G $\leq 0.7 \times 10^{6}$,

$$
\Phi_{\mathrm{LO}}^{2}=(\mathrm{ABC})(\mathrm{FMN})\left[1.36+0.0005 \mathrm{P}+0.1\left(\frac{\mathrm{G}}{10^{6}}\right)-0.000714 \mathrm{P}\left(\frac{\mathrm{G}}{10^{6}}\right)\right] \text {. }
$$

For $\mathrm{G} \geq 0.7 \times 10^{6}$

$$
\Phi \underset{\mathrm{LO}}{2}=(\mathrm{ABC})(\mathrm{FMN})\left[1.26-0.0004 \mathrm{P}+0.119\left(\frac{10^{6}}{\mathrm{G}}\right)+0.00028 \mathrm{P}\left(\frac{10^{6}}{\mathrm{G}}\right)\right] \text {. }
$$

If $\Phi_{\mathrm{LO}}^{2}<1$ in the above equations; $\Phi_{\mathrm{LO}}^{2}$ is set equal to one.

E

L. Second-Pass Inlet Conditions

Second-pass inlet enthalpy is calculated by the following equations:

$$
\begin{aligned}
& \mathrm{H}_{\text {in (2) } \mathrm{AC}}=\mathrm{H}_{\text {ln (1) }}+\mathrm{F}_{\mathrm{a}}(\Delta \mathrm{H}) \\
& \mathrm{H}_{\text {ln (2) HC }}=\mathrm{M}\left[\mathrm{H}_{\text {in (1) }}+\mathrm{F}_{\mathrm{a}}(\Delta \mathrm{H})\right]+(1-\mathrm{M}) \mathrm{H}_{\text {out (1) HC \#1, }} \\
& \mathrm{H}_{\text {in (2) HC }}=\mathrm{M}\left[\mathrm{H}_{\text {in (1) }}+\overline{\mathrm{F}}_{\mathrm{a}}(\Delta \overline{\mathrm{H}})\right]+(1-\mathrm{M})\left[\mathrm{H}_{\mathrm{ln}(1)}+(\Delta \mathrm{H})\left(\mathrm{F}^{\prime} \Delta^{\prime} \mathrm{I}_{\mathrm{mix}}\right)\right]
\end{aligned}
$$

where

$\Delta H$ is the first-pass $A C$ enthalpy rise,

$F_{a}$ is the fraction of flow heated,

$\mathrm{M}$ is the mixing factor,

$A C$ is the average channel,

$\mathrm{HC}$ is the hot channel,

(1), (2) is the first or second pass. 
Second-pass hot channel inlet enthalpy is calculated by Eq (1) if the input value $\mathrm{F} \Delta \mathrm{T}$ (mix) is zero, and Eq (2) if $\mathrm{F} \Delta \mathrm{T}_{(\mathrm{m} \mathrm{Lx})}$ is non-zero.

\section{INPUT - OUTPUT OPTIONS}

Three input options are avallable as follows:

1) Axlal variation of channel roughness may be accomplished by entering a (1) In column 59 on the input control card (Card 2): $A$ and $B$ factors $\left(f_{\text {iso }}=A / R e^{B}\right.$ ) must then be entered in pairs for each

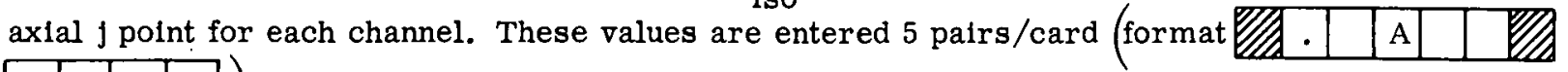
$\left.\begin{array}{|l|l|l|l}\hline . & & \text { B } & \\ \hline\end{array}\right)$. Every card but the last of the set must contain 5 pairs of values. No card number should be included. This set of cards must be placed between the normal set of input cards and'the blank card.

2) Axial variation of the heat transfer coefficient may be accomplished by entering a (2) in column 59 on the input control card (Card 2). Heat transfer coefficient multipliers must then be entered for

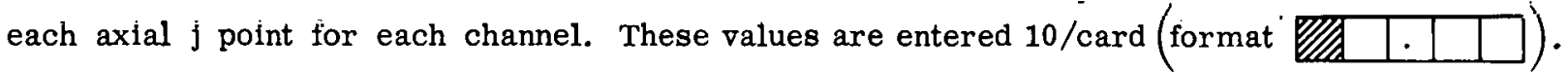
Every card but the last of the set must contain 10 values. No card number should be included. This selection also activates the axial variation of channel roughness option. Therefore, both sets of extra input cards must accompany this selection; roughness cards are followed by heat transfer multiplier cards. These card sets must be placed between the normal set of input cards and the blank card.

3) Convergence accuracy, the match of the true hot channel pressure drop (calculated by multiplying the average channel pressure drop by the plenum equation) to the actual hot channel pressure drop searched from the $G$ vs $\Delta P$ curve, is programmed as $2 \%$. This percentage may be altered by entering the desired value as a decimal in columns $60 \rightarrow 63$ as (Card 2).

Three output options are avaflable as follows:

1) A special hot channel edit* containing the following items may be obtained by entering a (1) in column 65 on the input control card (Card 2). This special edit contains:

a) $\mathrm{f} / \mathrm{f}_{\text {iso }}, \Phi_{\mathrm{LO}}^{2} \rho, \mathrm{v}_{\mathrm{b}}, \mathrm{f}_{\text {iso }}$ (for each $\mathrm{j}$ elevation),

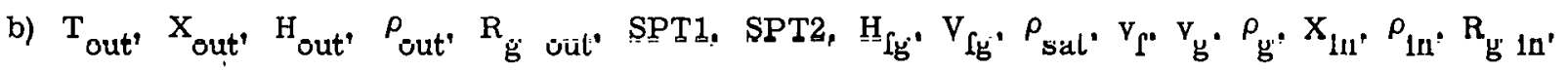
and $f_{\text {iso, sat }}$ (for the channel);

and the parameters are defined as follows:

$\mathrm{f} / \mathrm{f}_{\text {iso }} \quad$ Friction factor ratio for heating and local boiling

$\Phi \stackrel{2}{L}$ Ratio of two-phase frictional pressure drop gradient to the corresponding isothermal liquid gradient

$\rho \quad$ Average density of fluid in a particular axial section

*See page 5 of the sample output. 


\begin{tabular}{|c|c|}
\hline $\mathrm{v}_{\mathrm{b}}$ & Average specific volume of fluid in a particular axial section \\
\hline $\mathrm{f}_{\text {iso }}$ & Isothermal friction factor \\
\hline$T_{\text {out }}$ & Temperature of fluid out of the channel \\
\hline $\mathrm{X}_{\text {out }}$ & Quality of fluid out of the channel \\
\hline $\mathrm{H}_{\text {out }}$ & Enthalpy of fluid out of the channel \\
\hline Pout & Density of fluid out of the channel \\
\hline $\mathrm{R}_{\mathrm{g}, \text { out }}$ & Void fraction of fluid out of the channel \\
\hline $\left.\begin{array}{l}\text { SPT1 } \\
\text { SPT2 }\end{array}\right\}$ & Spatial acceleration terms as defined previously \\
\hline $\mathrm{H}_{\mathrm{fg}}$ & Enthalpy of vaporization \\
\hline${ }^{v_{f g}}$ & Specific volume of vaporization. \\
\hline$\rho_{\text {sat }}$ & Saturation density \\
\hline$v_{f}$ & Specific volume of fluid at saturation conditions \\
\hline $\mathbf{v}_{\mathrm{g}}$ & Specific volume of gas at saturation conditions \\
\hline${ }^{\rho} \mathrm{g}$ & Density of gas at saturation conditions \\
\hline $\mathrm{x}_{\text {in }}$ & Quality of fluid into the channel \\
\hline$\rho_{\text {in }}$ & Density of fluid into the channel \\
\hline $\mathrm{R}_{\mathrm{g}, \text { in }}$ & Void fraction of fluid into the channel \\
\hline $\mathrm{f}_{\text {iso, sat }}$ & Isothermal friction factor at the saturation temperature \\
\hline
\end{tabular}

2) An $x-y$ plot of the hot channel $G$ vs $\Delta P$ table may be obtained by entering a (1) in column 68 on the input control card (Card 2). (See page 3 of the Sample Output.)

3) A complete channel edit may be obtained for each flow step in the $G$ vs $\Delta P$ table. The information at each step will be identical to that produced for the hot channel solution. This option may be activated by instructing the computer operator to depress sense switch 3 . Using this option doubles the normal problem running time.

\section{INPUT FORM PREPARATION}

The STDY input forms are shown in Appendix I. Any other form containing a similar format may be used to submit problems for computation. These forms are not.interchangeable with input forms for previous versions of STDY. Instructions for completing the forms fullow.

\section{A. STDY Input Form (Page 1)}

Title Card - Card 1 contains the eight-digit problem number and the code name STDY-3. Any alpha-numeric identification information may be placed in the center spaces (columns 13 to 65 ). 
Control Card - Card 2 contains sixteen items of the following form:

1) \#P Number of system pressures to be read from Card 3 (range: 1 through 5).

2) \#G Number of normal channel flows to be read from Cards 4 and 5 (range: 1 through 5).

3) \#T Number of first-pass inlet temperatures to be read from Card 6 (range: 1 through 5).

4) \# $\varnothing \quad$ Number of channel heat flux variations to be read from Cards 71 to 75 as necessary (range: 1 through 5).

5) NP Number of passes (1 or 2).

6) N1C Number of first-pass channels (range: 1,2 , or 3 ).

7) N2C Number of second-pass channels. Must be zern for nne-pass cores (rangç: 0, 1,2 , or 3 ).

8) J Number of axial sections for heat transfer purposes (range: 2 through 30 ).

9) $\mathrm{K}_{\mathrm{clad}}$ Thermal conductivity of clad for meat temperature calculations $\left(\mathrm{Btu} / \mathrm{hr}-\mathrm{ft}-{ }^{\circ} \mathrm{F}\right)$.

10) $\mathrm{K}_{\text {meat }}$ Thermal conductivity of meat for meat temperature calculations $\left(\mathrm{Btu} / \mathrm{hr}-\mathrm{ft-}-{ }^{\circ} \mathrm{F}\right)$.

11). Channel Channel length (in.).

Length

12) Frac Flow Fraction of flow heated for second-pass Inlet enthalpy calculations only (see Heated equation below).

13) $\mathrm{F} \Delta \mathrm{T}_{\text {(mix) }}$ Hot channel factor to calculate alternate second-pass inlet enthalny. Second= pass inlet enthalpy is calculated by $\mathrm{Eq}$ (1) if $\mathrm{F} \Delta \mathrm{T}_{\text {(mix) }}$ is zero, and $\mathrm{Eq}$ (2) if $\mathrm{F} \Delta \mathrm{T}_{\text {(mix) }}$ is non-zero.

$$
\mathrm{H}_{\text {in }(2) \mathrm{AC}}=\mathrm{HI}_{\text {in }}+\mathrm{Fa}(\Delta \mathrm{H})
$$

$$
\begin{gathered}
\mathrm{H}_{\mathrm{in}(2) \mathrm{HC}}=\mathrm{M}\left[\mathrm{H}_{\mathrm{in}}+\mathrm{Fa}(\Delta \mathrm{H})\right]+(1-\mathrm{M}) \mathrm{H}_{\text {out }}{ }_{(1) \mathrm{HCH1}} \\
\mathrm{H}_{\mathrm{in}_{(2) \mathrm{IIC}}}=\mathrm{M}\left[\mathrm{H}_{\mathrm{in}}+\mathrm{Fa}(\Delta \mathrm{H})\right]+(1-\mathrm{M})\left[\mathrm{H}_{\mathrm{in}}+\left(\Delta \mathrm{H} \mathrm{F} \Delta \mathrm{T}_{\mathrm{mix}}\right)\right],
\end{gathered}
$$

where

$\Delta \mathrm{H}$ is the first-pass $\mathrm{AC}$ enthalpy rise,

Fa is the fraction of flow heated,

$M$ is the mixing factor supplied separately for each accond-pass hot chanuel on the plenum cards,

$\mathrm{AC}, \mathrm{HC}$ is the average channel or hot channel, respectively,

(1), (2) is the first or second pass, respectively. 
14) Starting Multiplier applied to the average channel flow to obtain the starting flow for the HC Flow G vs $\Delta \mathrm{P}$ table (should be $\geq 1$ ).

15) $\mathrm{EQ}$. Equation type (1), (2), or (3). (See Section II.)

(1) Design equations

(2) Bést fit equations

(3) Design equations (special DNB equations)

16) SOL : Hot channel solution selection $(1,2$, or 3$)$. A solution is defined as an intersection of the curve through the hot channel $G$ vs $\Delta P$ points and the average channel pressure drop times the plenum factor line. This intersection may. occur more than once for a particular problem.

(1) Prints the solution for the lowest flow.

(2) Prints the solution for the highest flow.

(3) Prints all solutions.

The first four numbers on the Control Card (Card 2) control the parameter variation provided for safety margin calculations. Each parameter will be varied independently through the set of values supplied, then reset to its initial value while any remaining parameters are varied. Only one parameter will be varied at a time; and once varied and reset, it will remain at its initial value for the remainder of the problem.

Pressure Card - Card 3 contains 1 to 5 pressures as indicated by the control card (psia).

$\left(\mathrm{lb} / \mathrm{hr}-\mathrm{ft}^{2}\right)$.

Flow Card - Card 4 contains 1 to 5 first-pass $G$ values as indicated by the control card

Flow Card - Card 5 contains 1 to 5 second-pass G values as indicated by the control card $\left(\mathrm{lb} / \mathrm{hr}-\mathrm{ft}^{2}\right)$. This card is not used for a one-pass problem.

$\underline{T}_{\text {in }}$ Card - Card 6 contains 1 to 5 first-pass inlet temperatures as indicated by the control $\operatorname{card}(\mathrm{F})$.

$\emptyset$ ave Card - Cards 71 through 75 contain 1 to 5 sets of channel heat fluxes as indicated by the Control Card (Btu/hr-ft ${ }^{2}$ ). Card 71 contains the first set of fluxes, Card 72 contains the second, etc. One to six values are punched per card depending on the number of channels. If any of Cards $72,73,74$, or 75 are not needed, they are not supplied.

B. STDY Input Form (Page 2)

Channel Description Cards - (Cards 81 through 86) One to six cards are supplied (equal to the number of channels) containing the following information:

THK $_{\text {ave }}$ is the channel average thickness (in.).

THK $_{\text {loc }}$ is the channel local thickness (in.). (May be left blank for normal channels.)

IK con is the contraction cocfficient. 
$\mathrm{K}_{\exp }$ is the expansion coefficient.

The contraction and expansion coefficients are used to calculate entrance and exit unrecoverable pressure drop by the following equation:

$$
\Delta P_{E \& E}=\frac{G^{2}}{2 g_{c}}\left(\frac{K_{\text {con }}}{\rho_{\text {in }}}+\frac{K_{\text {exp }}}{\rho_{\text {out }}}\right) \text {, }
$$

where

$\mathrm{G}$ is the mass flowrate $\left(\mathrm{lb} / \mathrm{hr}-\mathrm{ft}^{2}\right)$, $\mathrm{g}_{\mathrm{C}}$ is the acceleration of gravity $\left(32.2 \mathrm{ft} / \mathrm{sec}^{2}\right)$, $\rho$ is the bulk fluid density $\left(\mathrm{lb} / \mathrm{ft}^{3}\right)$.

a is a constant.

b is a constant.

These constants are used to describe the channel friction factor by the following equation:

$$
f_{\text {iso }}=\frac{a}{(R e)^{b}} \text {, }
$$

where Re is the Reynold's Number.

THK $_{\text {clad }}$ is the clad thickness (in.).

THK $_{\text {meat }}$ is the meat thickness (in.) ( $g$ and $h$ may be left blank for normal channels).

$\sigma_{\text {In }}$ is the entrance area ratio.

$\sigma$ out is the exit area ratio.

These $\sigma$ terms are used to calculate the configuration accelerations at the entrance and exit of the channel (smaller area/larger area).

$F_{\emptyset \text { ave }}$ is the average hot channel factor affecting heat flux (must be supplied for all channels). $F_{\phi 10 c}$ is the local hot channcl factor affceting heat flux (may be left blank for normal channels).

Plenum Cards - (Cards 91 through 94) Zero to four plenum cards must be supplled depending on the number of hot channels. These cards contain the $\mathrm{K}$ values as used in the following equation:

$$
\begin{aligned}
\Delta \mathrm{P}_{\mathrm{HC}} & =\mathrm{K}_{1} \mathrm{~K}_{2}\left(\Delta \mathrm{P}_{\mathrm{AC}}\right) \text { thtal }+\left(1-\mathrm{K}_{1} \mathrm{~K}_{2}\right)\left(\Delta \mathrm{P}_{\mathrm{AC}}\right) \text { clcvation } \\
& +\mathrm{K}_{1} \mathrm{~K}_{2}^{i} \mathrm{~K}_{2}^{j}+\mathrm{K}_{2} \mathrm{~K}_{1}^{\prime}-\mathrm{K}_{1} \mathrm{~K}_{2}\left(1+\mathrm{K}_{1}^{\prime}\right)\left(\Delta \mathrm{P}_{\mathrm{AC}}\right) \text { acceleration, }
\end{aligned}
$$

where $\mathrm{HC}$ is the hot channel and $\mathrm{AC}$ is the average channel. These cards also contain the $\mathrm{M}$ factors necessary to the previously described second-pass inlet enthalpy equations.

Axial Flux Weighting Cards - (Cards 01 through 18) One to eighteen $f^{\prime}(z)$ cards must be supplied as the last set of input. These values weight the average heat flux axially. One value for each axial point (J) for each channel must be supplied. These values are supplied up to ten/card; a new card is begun for each channel.

One blank card must follow each complete set of input data. This blank card is checked by the machine; if not supplied, the problem will be rejected. Successive problems may be submitted by stacking the sets of input data. 
Certain input form blanks show a decimal point while certain others show a decimal and a sign. Values supplied in these spaces must go directly to the right or left of the decimal. The spaces to the right of a sign are available for powers of ten (e.g., $2.200+06$ is interpreted as $2.2 \times 10^{6}$ ); blank spaces are interpreted by the machine to be zeros.

\section{ESTIMATED RUNNING TIME}

Problem running time, neglecting program loading, may be estimated by the following formula:

$$
\text { Running time (minutes) }=0.009[(\# P-1)+(\# G-1)+(\# T-1)+(\# \emptyset)](N 1 C+N 2 C)-J
$$

The above quantities are seven of the first elght values entered on Card 2 for the problem in question.

\section{SAMPLE INPUT AND OUTPUT}

Sample input and output sheets are shown in Appendix $\Pi$.

\section{MACHINE OPERA'TING INSTRUCTIONS}

The STDY-3 code is designed to operate on an IBM-704 computer having a core storage of 16,384 words, an on-line card reader, an on-line 716 printer, one logical drum, and from one to three tape units. In addition, an off-line 717 printer is required.

1) The on-line printer board must be Share-2.

2) Tapes are normally only a blank 5 for problem output. If sense switch 3 option is requested, ready a blank 6 .

3) Sense switches are normally all up. Switch 3 is down if requested.

4) Ready the card reader with the self-loading program deck followed by the data deck(s). One blank card must follow each data set.

5) Push the CLEAR and LOAD CARDS buttons.

6) End of run is signaled by a read select on the card reader and an "end of this problem" printed on line.

7) Output is normally only on tape 5. No rewind or end-of-file operations are programmed. A manual end-of-file should be written on the output tape before rewinding.

The code checks Input cards for obvious errors. If an error is found, the substance of the error is printed on-line and the remainder of that particular problem input is run through the card reader. When a blank card is encountered, the erroneous problem is assumed to cease and a new problem to begin. A blank card at the end of each problem is therefore absolutely necessary to the proper functioning of this program.

To transfer computer control to the logical beginning of the program (to start a new problem or retry an old one), ready the data cards in the card reader and manually transfer to location (00155) ${ }_{8}$ (program tape), or location $(00024)_{8}$ (program cards).

An estimated maximum running time is printed on-line for each problem. If a particular problem runs more than 5 minutes over the estimated time, an error should be assumed and the problem stopped: 


\section{ACKNOWLEDGMENTS}

The writer is grateful to Mr. J. D. Wilde for his work on the original IBM-650 version of STDY and to Mr. G. J. Mohn for his assistance during the programming of STDY for the IBM-704. The curve fit equations for the "Heat Transfer Coefficient" and the "Famlly of Curves" representing bulk bolling pressure drop data were supplied by the Bettis Thermal and Hydraulics Section.

\section{RE FERENCES}

1. J. E. Meyer, et al., "ART - A Program for the Treatment of Reactor Thermal Transients on the IBM704," WAPD-TM-156 (November 1959).

2. N. C. Sher and S. J. Green, "Boiling Pressure Drop in Thin Rectangular Channels," Nuclear Eng1neering-Part VI, Chemical Engineering Progress Symposium Series, No. 23, Vol 55 (1959), Fig. 12, p 69.

3. R. C. Martinell and D. B. Nelson, "Prediction of Pressure Drop during Forced Circulation Boiling of Water," Trans. ASME, Vol 70 (1948), p 695.

4. N. C. Sher, "Review of Martinell1 - Nelson Pressure Drop Correlation, "WAPD-TH-219 (July 1956), Table I, p 11. 


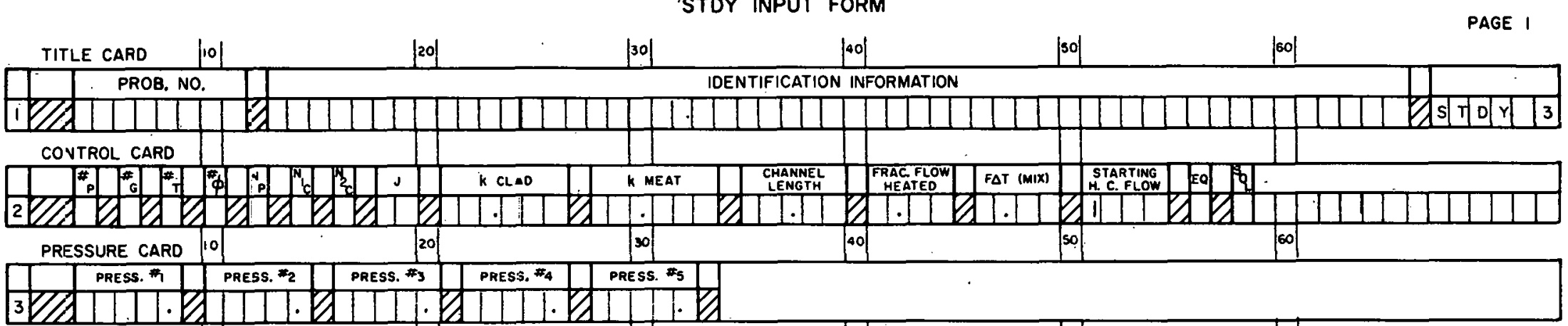

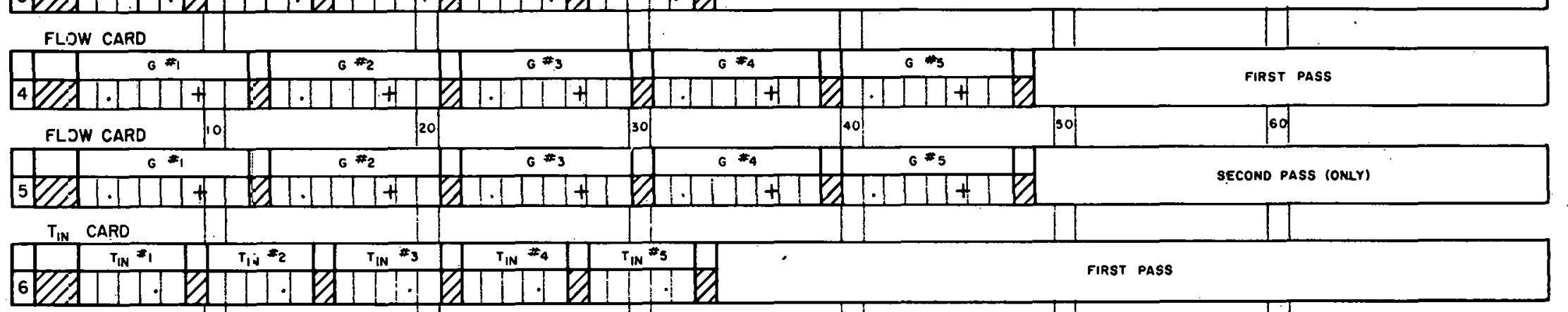

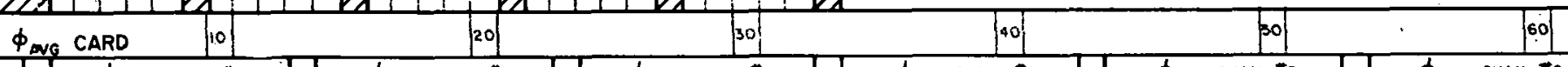

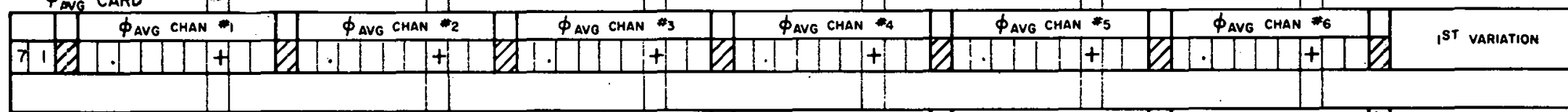

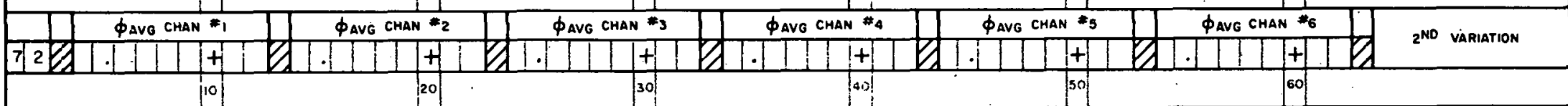

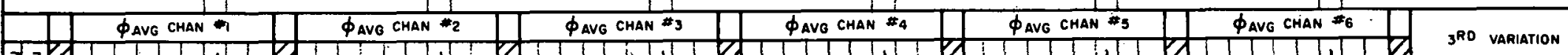
73.

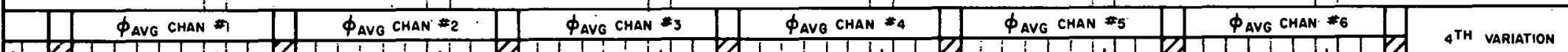

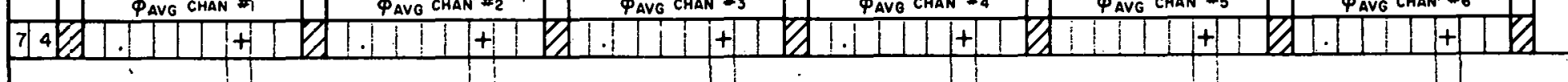

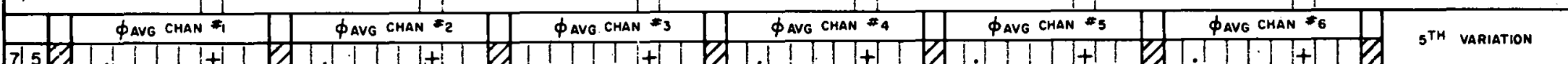

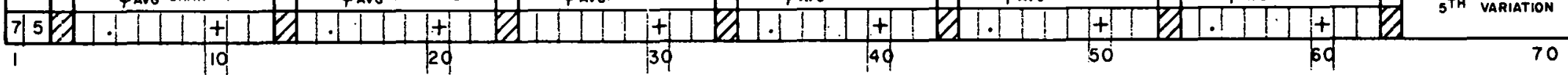


CHANNEL DISERIPTION CAROS

CHAN $* 1$

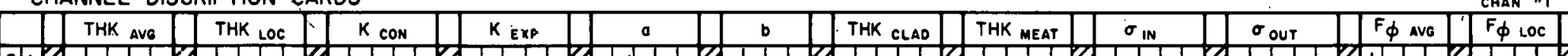
8.1.

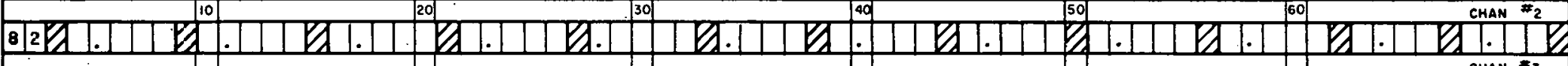

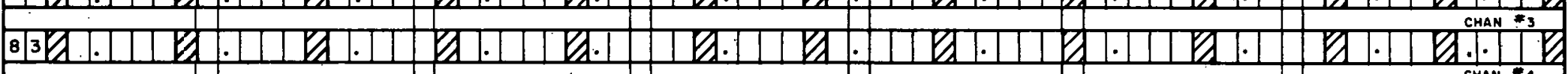

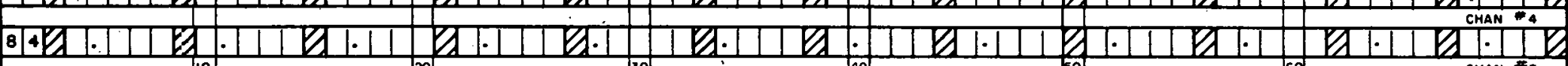
100

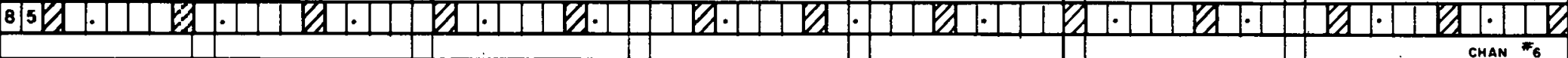

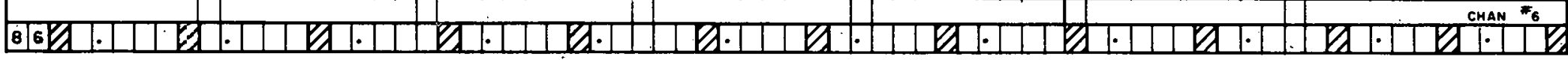
PLENUM CAROS

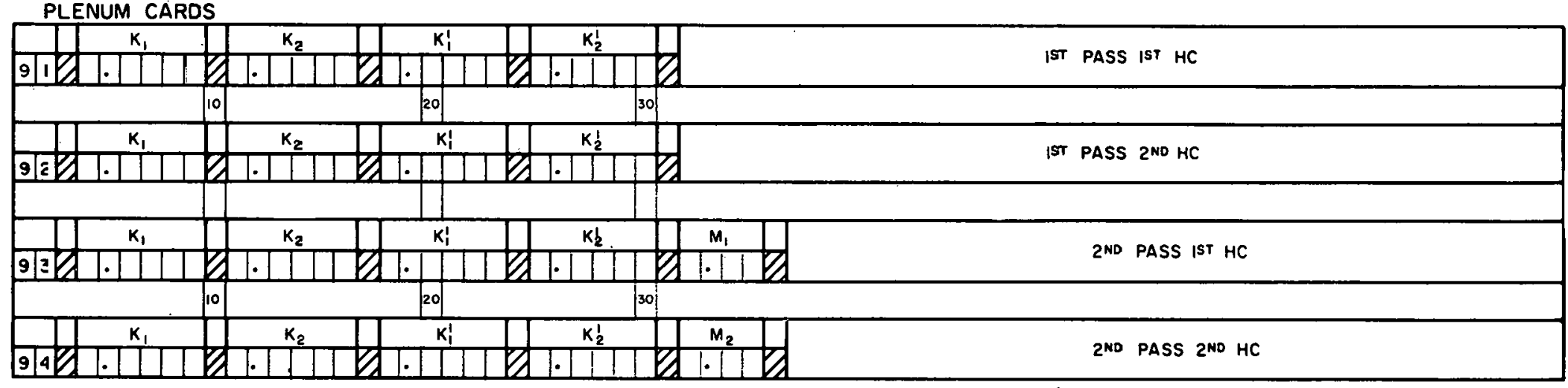

AXIAL FLUX WEIGHTINE CARDS - $f^{\prime}(Z)$

(START A NEW CARD FOR EACH CHANNEL)

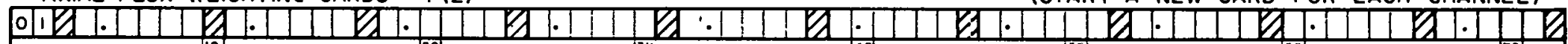

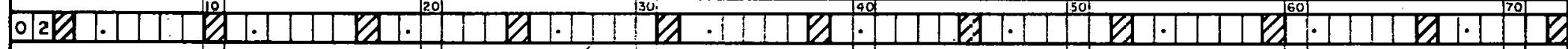

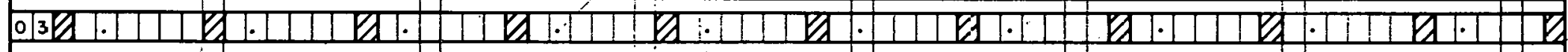

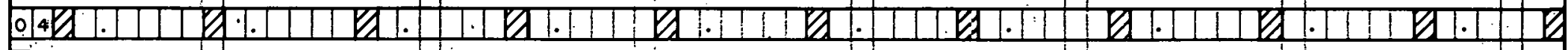

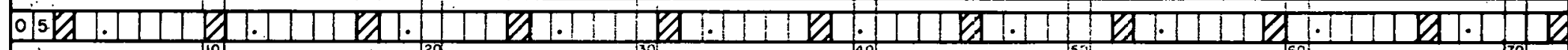

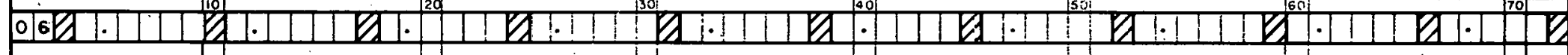

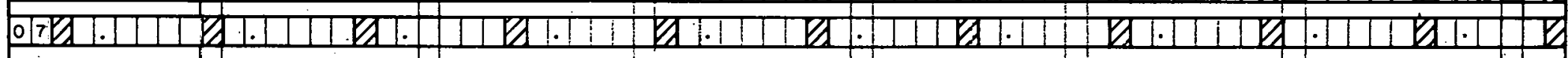

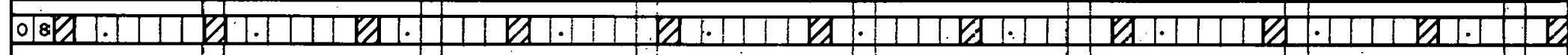

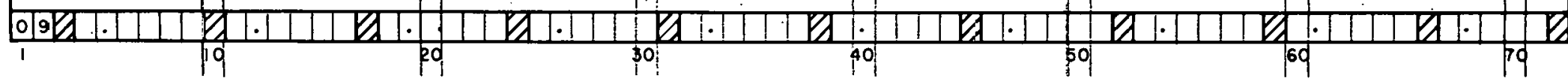


Sample Input

(Hypothetical Reactor)
10626.9305
TEST PROBLEM
R.S. PYLE
STDY 3
$\begin{array}{lllllllllllll}2 & 1 & 1 & 1 & 1 & 1 & 2 & 0 & 10 & 7.4 & 7.4 & 41 . & .84\end{array}$
1. 11
11
31800 .
$45.66+06$
$6 \quad 473.8$
$712.5000+05 \quad 3.5000+05$

$\begin{array}{lcccccccccccc}81 & .085 & & .323 & .304 & .1439 & .169 & & & .447 & .447 & 1 . & . \\ 82 & .078 & .086 & .333 & .333 .1195 & .150 & .015 & .081 & .421 & .421 & 1.12 & 1.17 \\ 91 & 1.0 & .827 & 1.0 & 1.0 & & & & . & & & & \\ 01 & 1.29 & 1.28 & 1.44 & 1.41 & 1.22 & 1.01 & .82 & .64 & .46 & .43 \\ 02 & 2.72 & 2.70 & 3.04 & 2.98 & 2.99 & 2.47 & 2.01 & 1.57 & 1.13 & 1.05\end{array}$


06269305

TEST PROBLEM R•.j• PYLE

STOY 3

STDY 3 *** PAGE 1

**** INPUT AS STORED IN MEMORY ****

$\begin{array}{lllllllllllllllllllllll} & 2 & 1 & 1 & 1 & 1 & 2 & 0 & 10 & 7.400 & 7.400 & 41.00 & 0.84 & -0 & 1.00 & 1 & 1\end{array}$

PRESSURE- $\quad 3 \quad \$ 800$.

FLOW- $\quad .4 \quad 5.660 E$ O6

TIIN) $\quad 6 \quad 4.73 .3$

FLUX 71 2.5000E $05 \quad 3.5030 E 05$

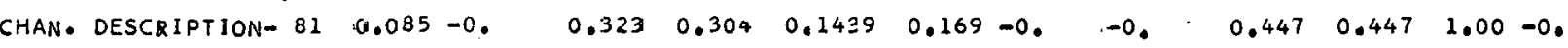

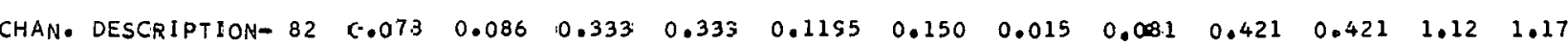

IST PASS PLENUM- $91 \quad 1.001000 .827 \mathrm{C} \quad-.0000 \quad 1.000 \mathrm{C}$

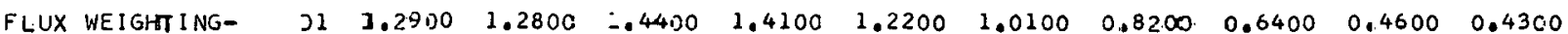

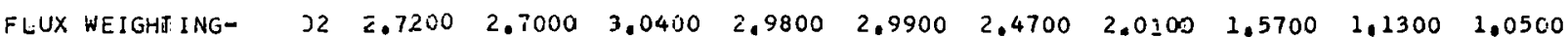

Page 1 - Repeat of Input Date

as Read from Input Cards 


\section{TAPE 5 aVERAGe CHANNEL VALUES (FIRST PASS)}

PRESSURE $=1800$. AVERAGE CHANNEL- HEAT FLUX $=2.5000 E$ 25, THICKNESS $=0.085$, LENGTH=41.00, INLET TEMP. $=473.8, H=457.5$

$\begin{array}{rrrr}J . & \text { T AVE } & \text { H AVE } & \text { X } \\ 1 & 476.20 & 460.26 & 0 \\ 2 & 480.99 & 465.74 & 0 \\ 3 & 486.02 & 471.53 & 0 \\ 4 & 491.27 & 477.61 & 0 \\ E & 496.08 & 483.21 & 0 \\ 6 & 500.14 & 487.96 & 0 \\ 7 & 503.45 & 491.86 & 0 \\ \varepsilon & 505.08 & 494.97 & 0 \\ 9 & 508.06 & 497.31 & 0 \\ 10 & 509.66 & 499.21 & 0\end{array}$

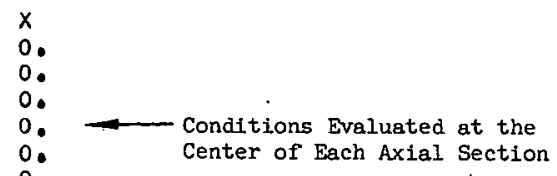

CHANNEL NUMBER $=1$ CHANNEL MASS VELOCITY $(G)=5.6 E .0 E 06 \quad$ ENTHALPY RISE $(B T U / L B)=42.61$

ACCELERATION $D P=0.444(:),-0.177(2)$ ELEVATION $D F=1.174$ FRICTION $D P=22.086$ ENTRANCE + EXIT DP $=3.365$ CHANNEL TOTAL PRESSURE DROP $=26.890$ AVERAGE CHANNEL PRESSURE DROP X PLENUM FACTOR $=22.487$ LOCAL BOILING STARTS $J=0 \quad$ BULK BOILING STARTS $J=0$

T $S A T=621.15 \quad$ H SAT $=649.12 \quad$ Average Channel MASS VELOCI TY VERSUS PRESSURE OROP TABLE
IST HOT CHANNEL

\section{$G=5.660 E$ O6 $D P=34.896$}

$G=5.377206 \quad D P=33.898$

$G=5.0911=06 \quad D P=31.767$

$G=4.528=06 \quad D P=29.0502$

$G=4.245=06 \quad D P=27.483$

$G=3.962=08 \quad D P=26.487$

$G=3.679=06 \quad D P=24.913$

$G=3.396 \mathrm{E}$ 06 $D P=24.481$

$G=3.113 E$ O6 $\quad D P=23.328$

$G=2.830 E$ 06 $\quad D P=23.144$

$G=2.547 E$ D $6 \quad D P=22.299$

$G=2.264 E$ O6 $\quad D P=21.968$

$G=1.981 E$ 06 $\quad D P=21.014$

$G=1.698 E$ O6 $\quad D P=20.397$

$G=1.415 E$ O6 $\quad D P=19.532$ 


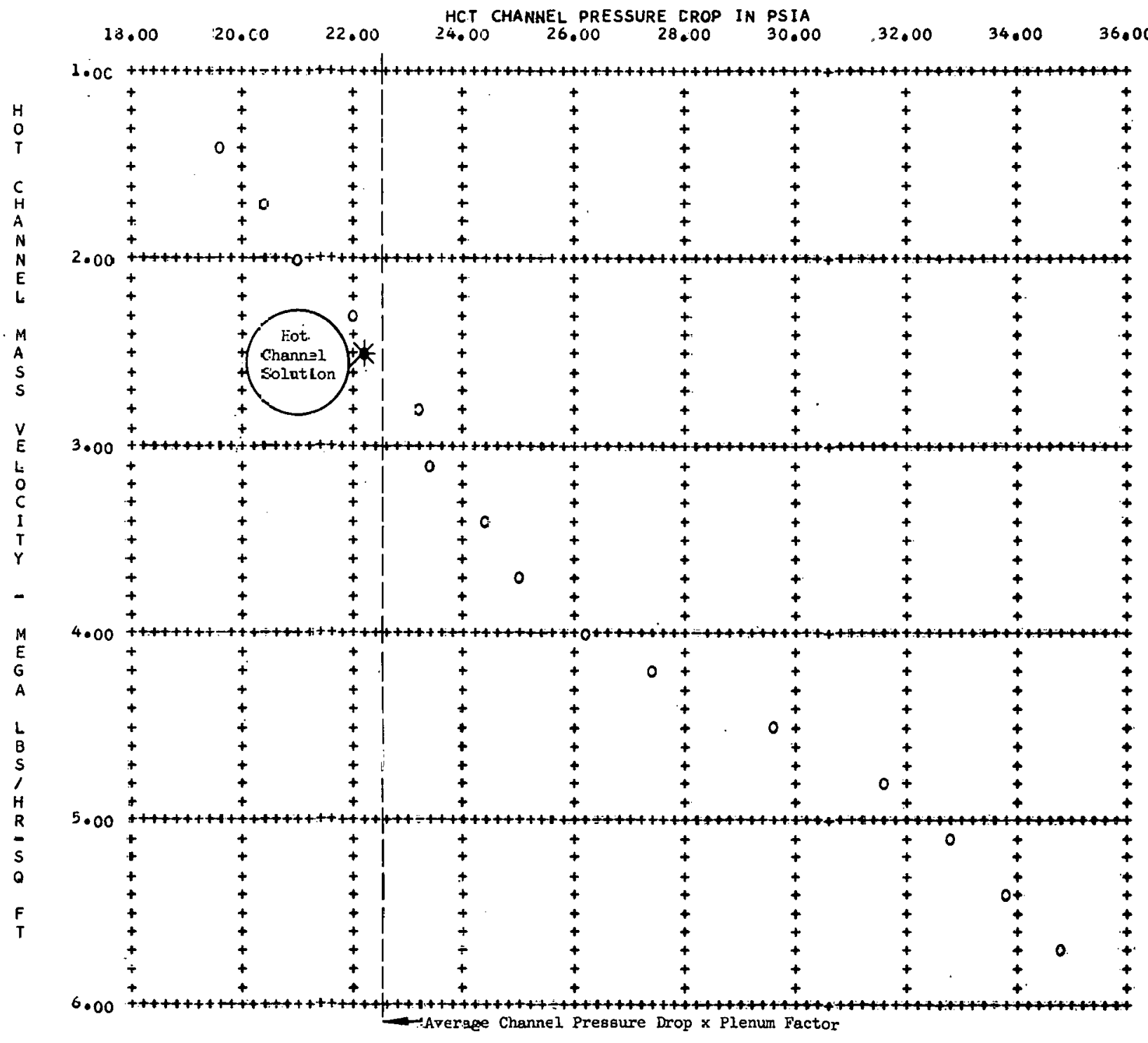




00269305 TEST PROB.EM R.S. PYLE

TAPE 5 HOT CHANNEL VALUES - SOLUTION NUMBER I

0

PRESSURE $=1800$, HOT CHANNEL- HEAT FLUX $=3.5000 E$ 05, THICKNESS $=0.078$, LENGTH=41.00, INLET TEMP. $=473.8$, H=457.5

$\begin{array}{rrr}J & \text { T AVE } & \text { HAVE } \\ 1 & 492.91 & 479.52 \\ 2 & 529.70 & 523.37 \\ 3 & 566.53 & 569.80 \\ 4 & 602.52 & 618.51 \\ 5 & 621.15 & 666.80 \\ 6 & 621.15 & 7.10 .97 \\ 7 & 621.15 & 747.22 \\ 8 & 621.15 & 776.18 \\ 9 & 621.15 & 798.02 \\ 10 & 621.15 & 815.66\end{array}$

$x$
0.0
0.1
0.1
0.035
0.035
0.123
0.195
0.253
0.296
0.331

$1 \mathrm{~s}$
629.40

629.38

629.63

629.59

629.60

629.20

628.80

627.77

627.65

TM DNBR

$\begin{array}{ll}1071.55 & 1.314 \\ 1068.28 & 1.167\end{array}$

$1123.80 \quad 0.915$

1115.63

1030.71

955.53

$1.1 .46 \quad 0.733$

CHANNEL NUMBER $=2 \quad$ CH.ANNEL MASS VELOCITY(G) $=2.547 E$ O6
06

ENTHALPY RISE (BTU/LB) $=366.64$

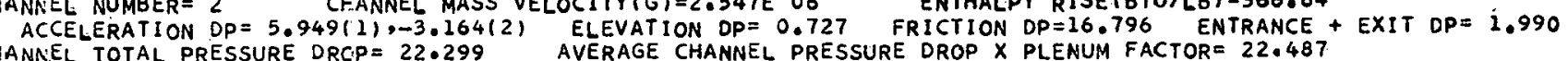

LOCAL BOILING STARTS J $=1$
$T$ SAT $=621.15$ H SAT $=6.49 .12$ 
06269305

TEST PRCB:EM

R.S. PYLE

STOY 3

STOY 3 "** PAGE 5

* special hot chalinel edit *

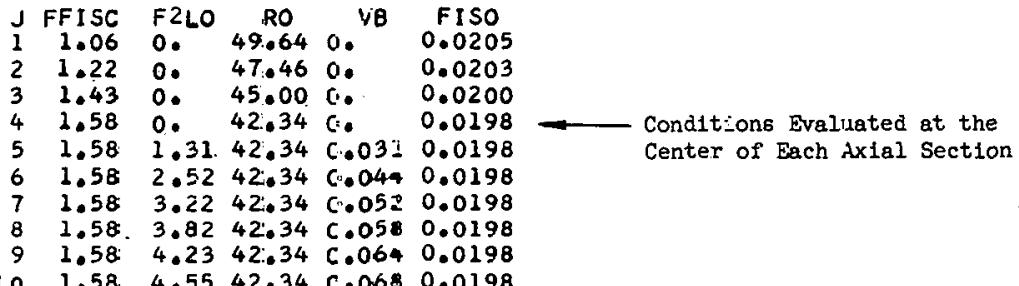

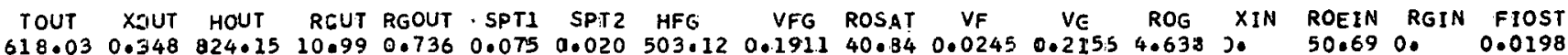

END JF THIS PROBLEM

This Page Oniy if Fequested.

\begin{tabular}{|c|c|c|c|c|c|}
\hline \multicolumn{2}{|c|}{ Key } & \multicolumn{2}{|c|}{ Key } & \multicolumn{2}{|c|}{ Key } \\
\hline FFISG & $=f / r_{130}$ & SPTI & $=\operatorname{SPRI}$ & ROEIN & $=\rho_{\text {in }}$ \\
\hline F2LC & $=\Phi_{L}^{2}$ & SPT2 & $=\operatorname{ses} 2$ & RGIN & $=\mathrm{R}_{z \text {, in }}$ \\
\hline Ro & $=0$ & FFG & $=\mathrm{H}_{\mathrm{f} E}$ & FIOST & $=f_{\text {iso, sat }}$ \\
\hline vB. & $=J_{B}$ & VFG & $=v_{\mathfrak{f} \varepsilon}$ & & \\
\hline FISO & $=P_{\text {iso }}$ & ROSAT & $=\rho_{\xi \in t}$ & & \\
\hline TOUT & $=q_{\text {out }}$ & $\mathrm{vF}$ & $=v_{f}$ & & \\
\hline XOUT & $=x_{\text {out }}$ & vG & $=v_{B}$ & & \\
\hline Hour & $=\sharp_{\text {out }}$ & ROG & $=o_{B}$ & & \\
\hline ROUT & $=\rho_{\text {out }}$ & XIN & $=x_{i n}$ & & . \\
\hline
\end{tabular}




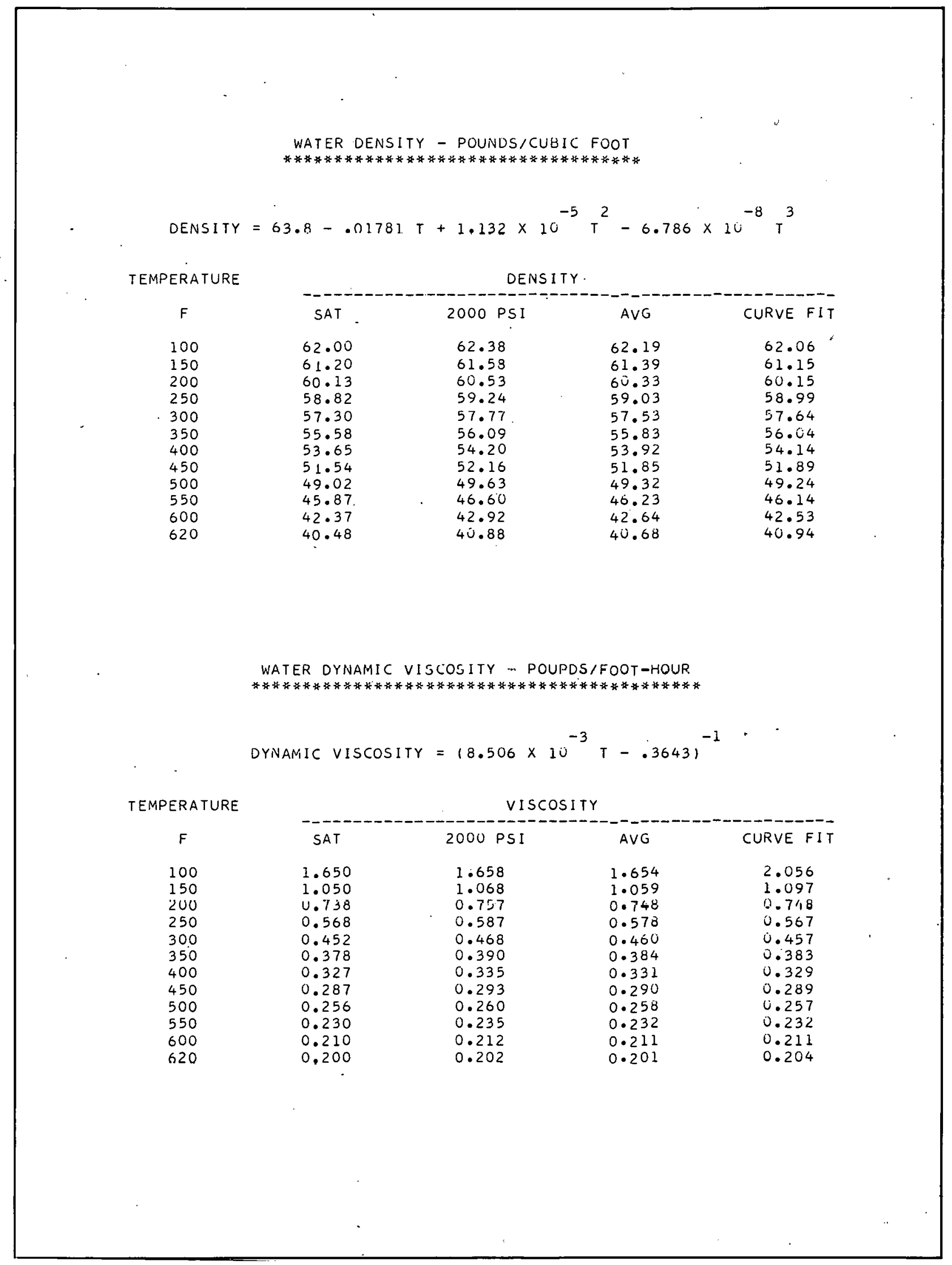




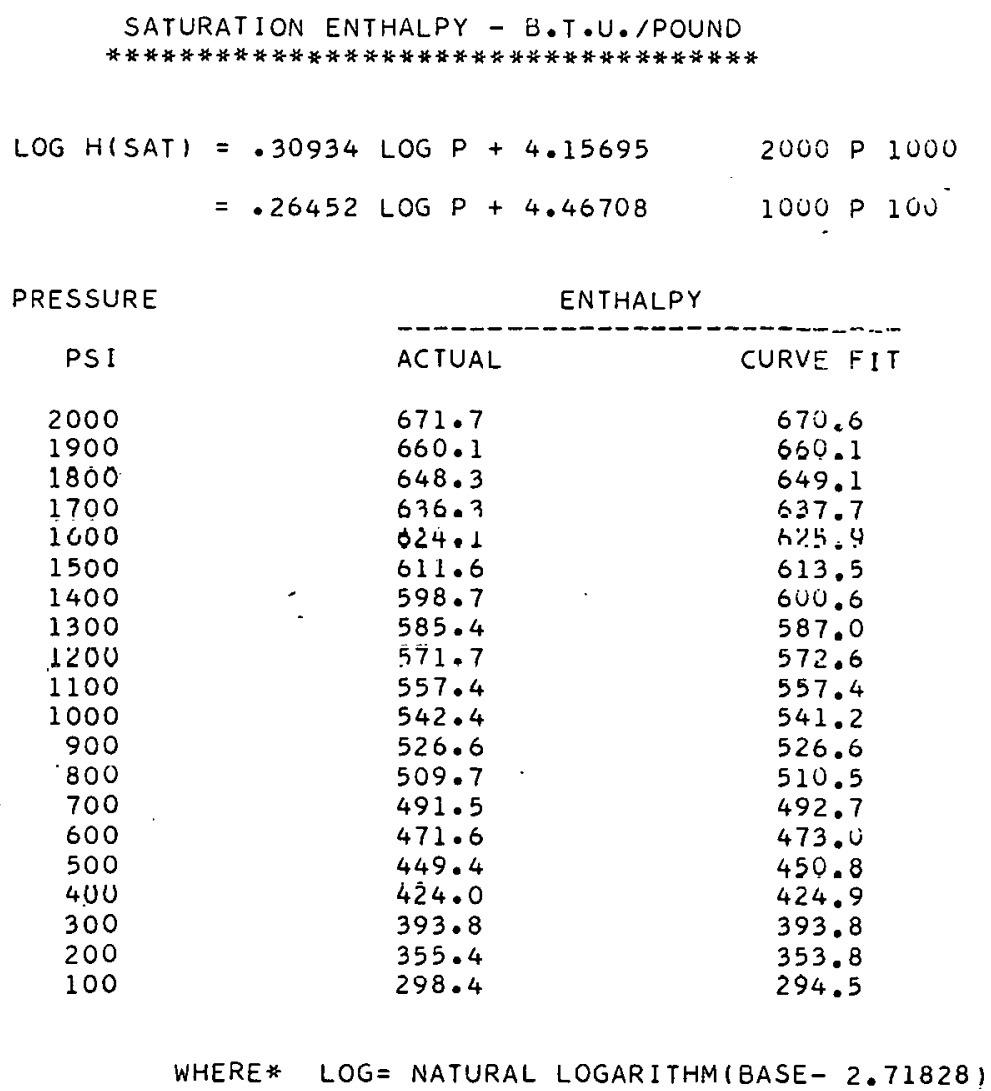




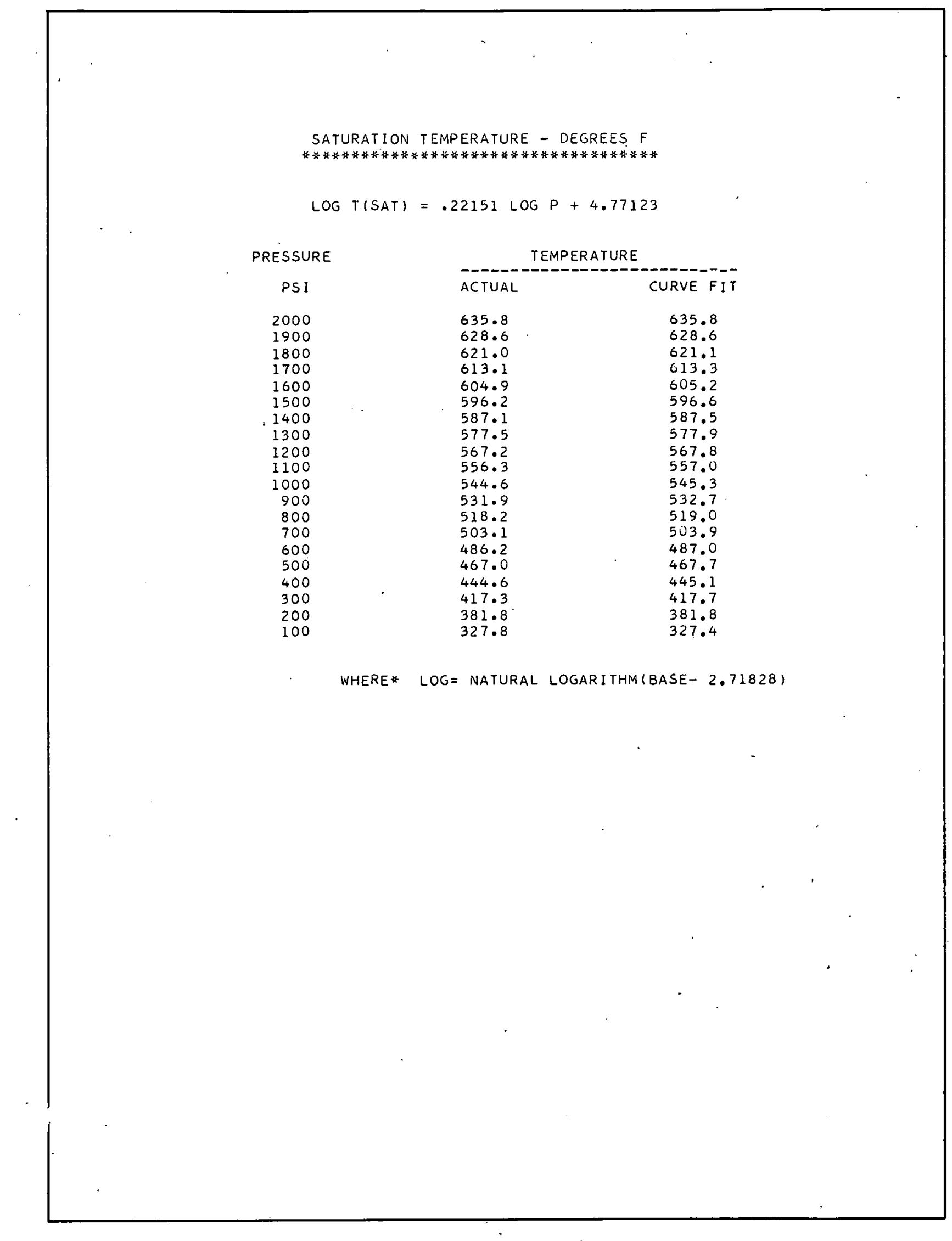




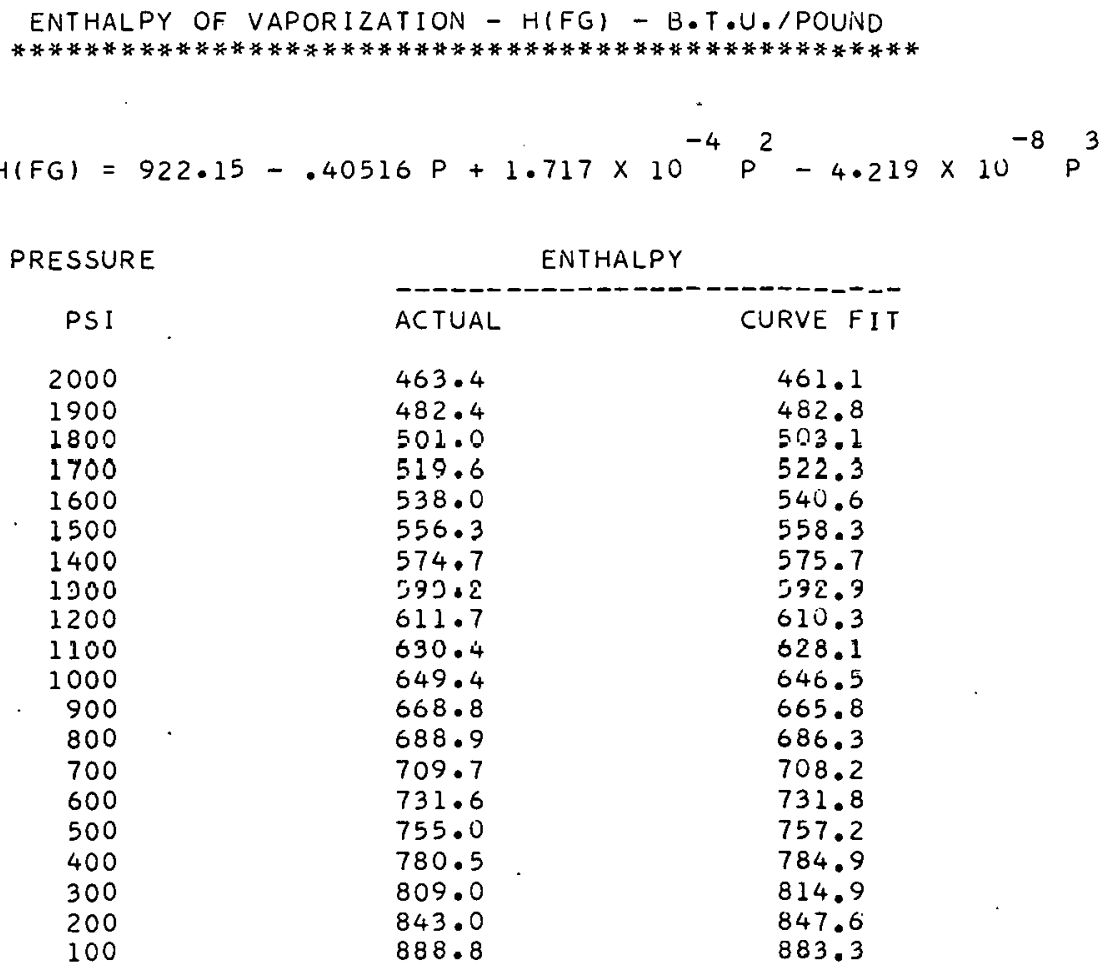


SPECIFIC VOLUME OF VAPORIZATION - VIFG) - CUBIC FEET/POUND

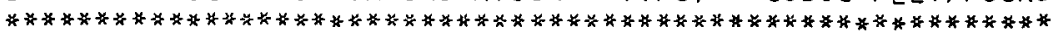

$$
\begin{aligned}
V \cdot(-F G) & =524.0(P)^{-1}-.100 \cdot 2000 P 300 \\
& =428.8(P)^{-1}+.126 \quad 300 P 100
\end{aligned}
$$

\begin{tabular}{ccc} 
PRESSURE & \multicolumn{2}{c}{ SPECIFIC VOLUME } \\
PSI & ACTUAL & CURVE FIT \\
& & \\
2000 & 0.1621 & 0.1620 \\
1900 & 0.1769 & 0.1758 \\
1800 & 0.1932 & 0.1911 \\
1700 & 0.2111 & 0.2082 \\
1600 & 0.2309 & 0.2275 \\
1500 & 0.2530 & 0.2493 \\
1400 & 0.2781 & 0.2742 \\
1300 & 0.3066 & 0.3031 \\
1200 & 0.3396 & 0.3367 \\
1100 & 0.3781 & 0.3764 \\
1000 & 0.4240 & 0.4240 \\
900 & 0.4794 & 0.4822 \\
800 & 0.5478 & 0.5550 \\
700 & 0.6349 & 0.6486 \\
600 & 0.7497 & 0.7733 \\
500 & 0.9081 & 0.9480 \\
400 & 1.1420 & 1.2100 \\
300 & 1.5244 & 1.6467 \\
200 & 2.2690 & 2.2700 \\
100 & 4.4140 & 4.4140
\end{tabular}


TEMPERATURE - ENTHALPY

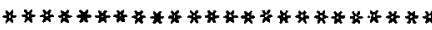

ACTUAL VALUES

TEMPERATURE

$F$

100

150

200

250

300

350

400

450

500

550

600

820
ENTHALPY

$\begin{array}{rrrr} & 1000 P S I & 1500 \text { PSI } & 2 U U O \text { PSI } \\ 68.0 & 70.7 & 72.0 & 73.3 \\ 117.9 & 120.4 & 121.6 & 122.8 \\ 168.0 & 170.2 & 171.4 & 172.5 \\ 218.5 & 220.5 & 221.6 & 222.6 \\ 269.6 & 271.3 & 272.3 & 273.2 \\ 321.6 & 322.9 & 323.7 & 324.5 \\ 375.0 & 375.8 & 376.4 & 377.0 \\ 430.1 & 430.4 & 430.7 & 431.1 \\ 487.8 & 487.6 & 487.5 & 487.4 \\ 549.3 & & 548.5 & 547.6 \\ 616.8 & & & 614.5 \\ 640.5 & & & \end{array}$

(CONT INUED) 


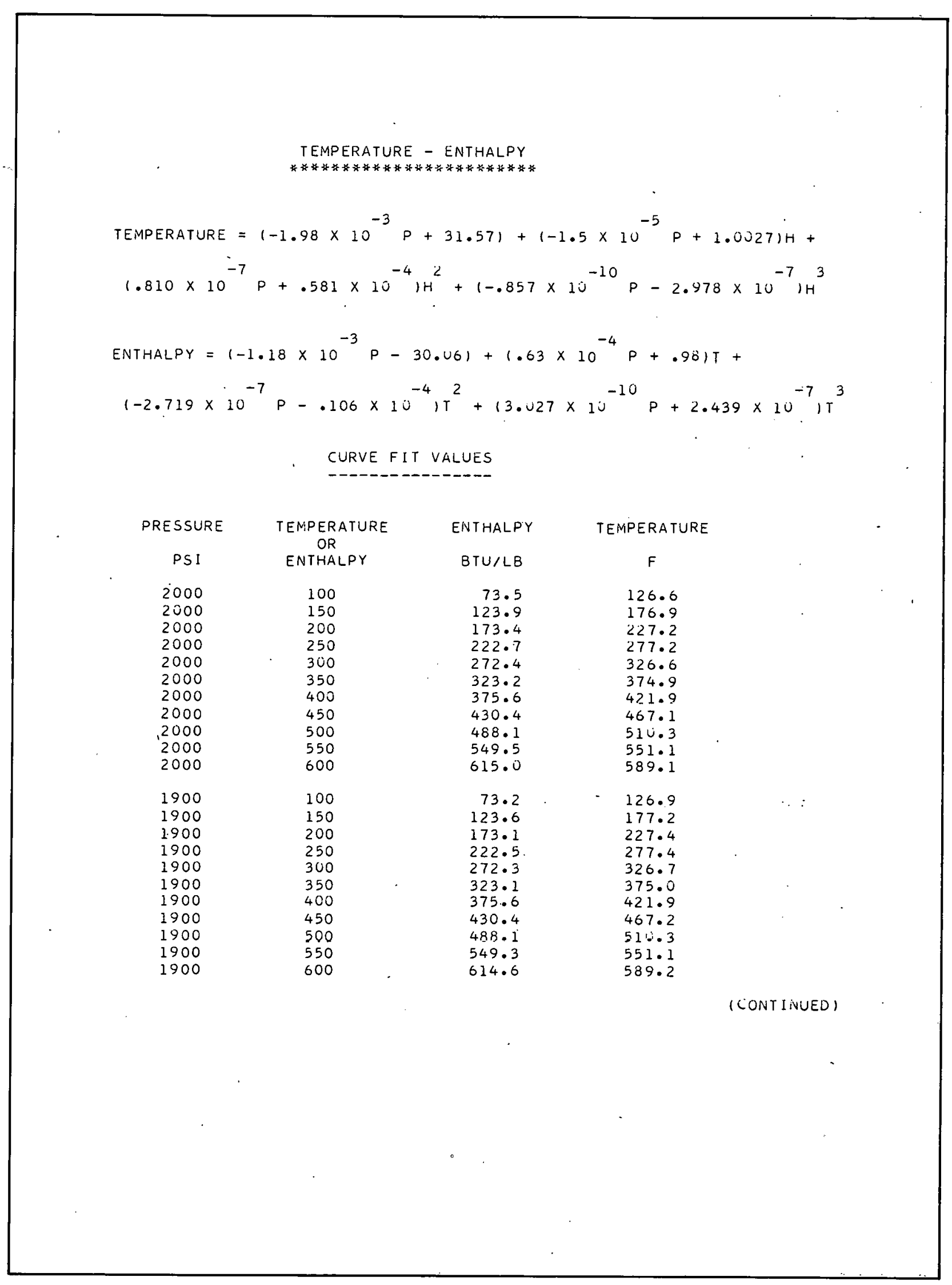




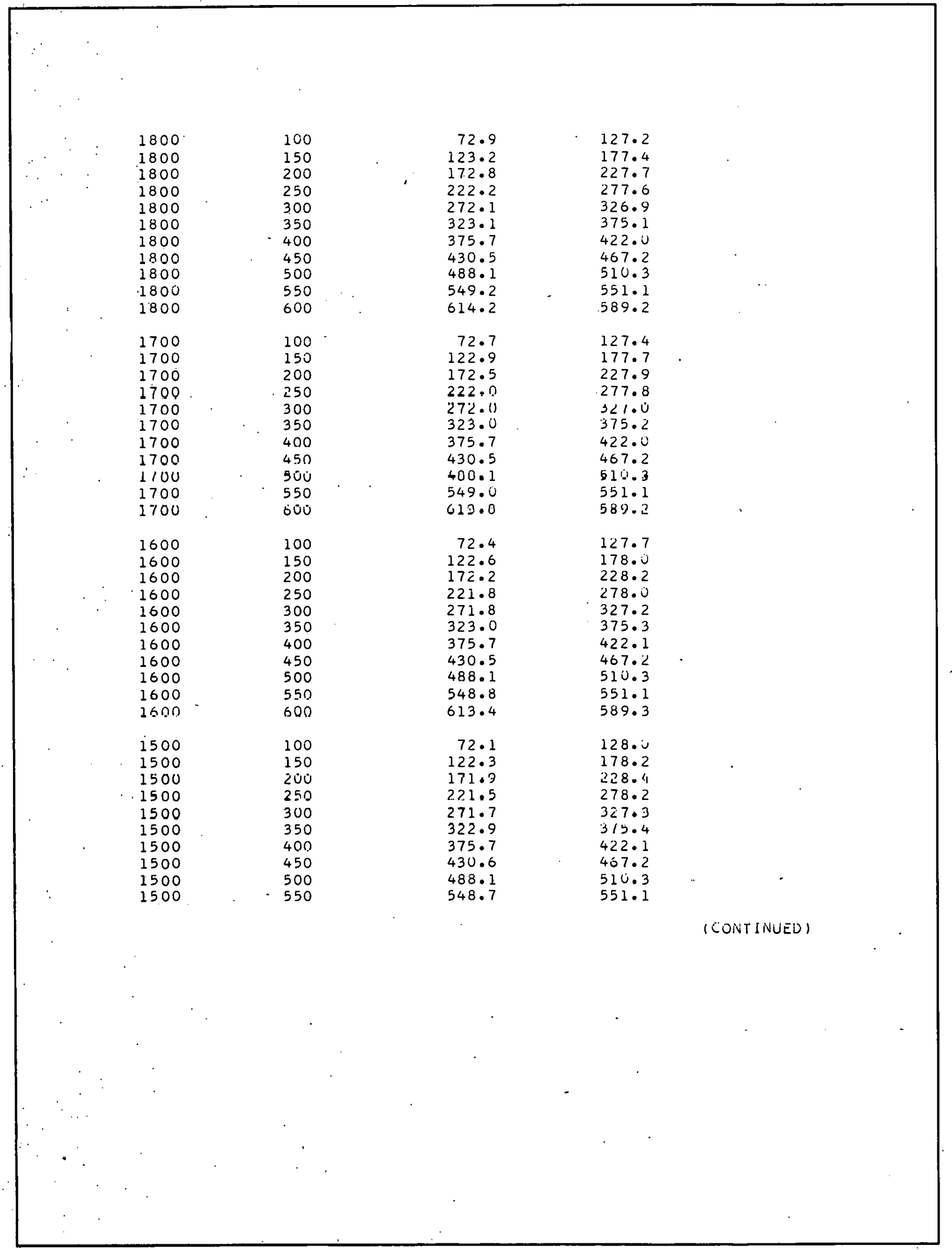




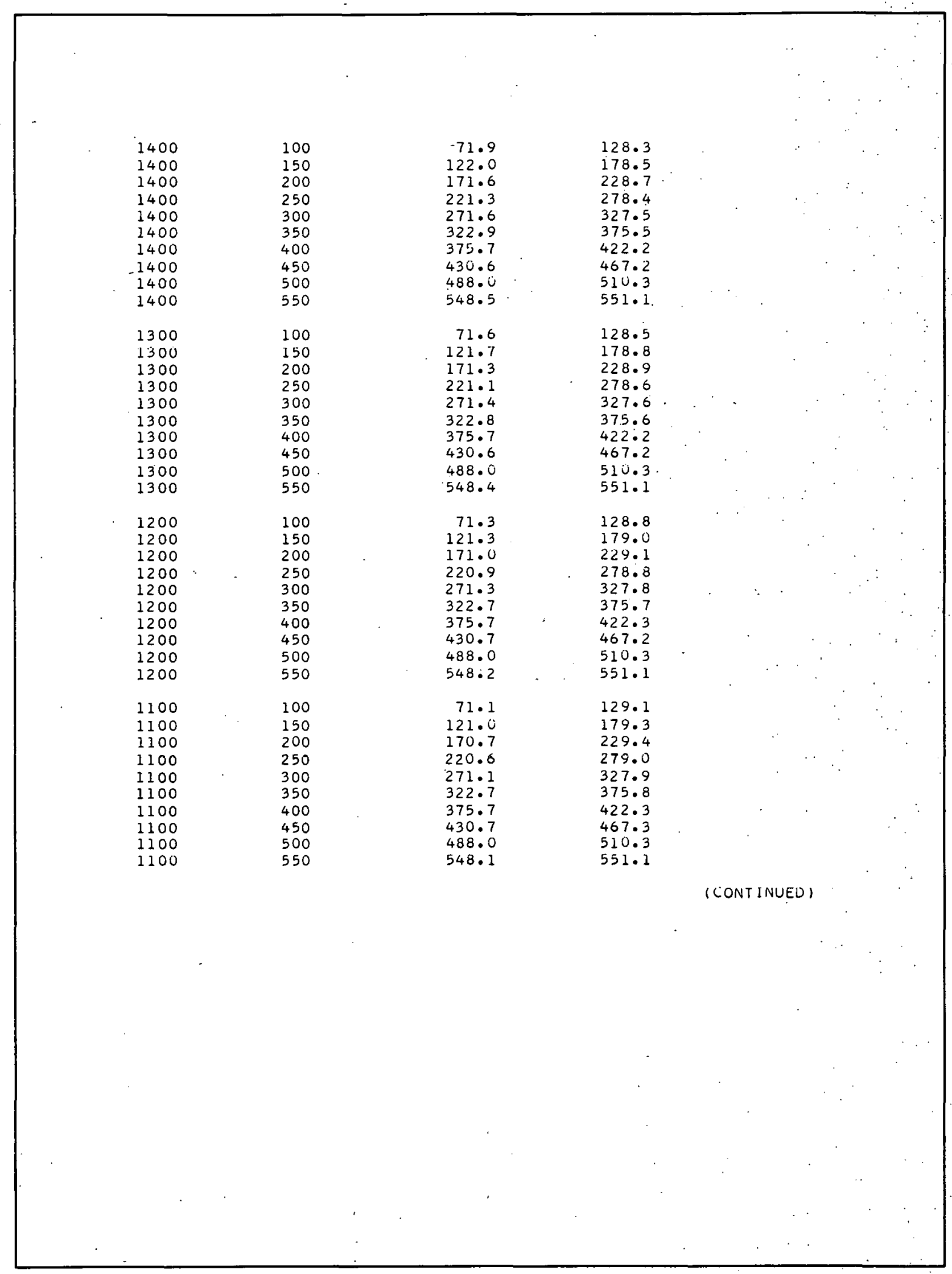




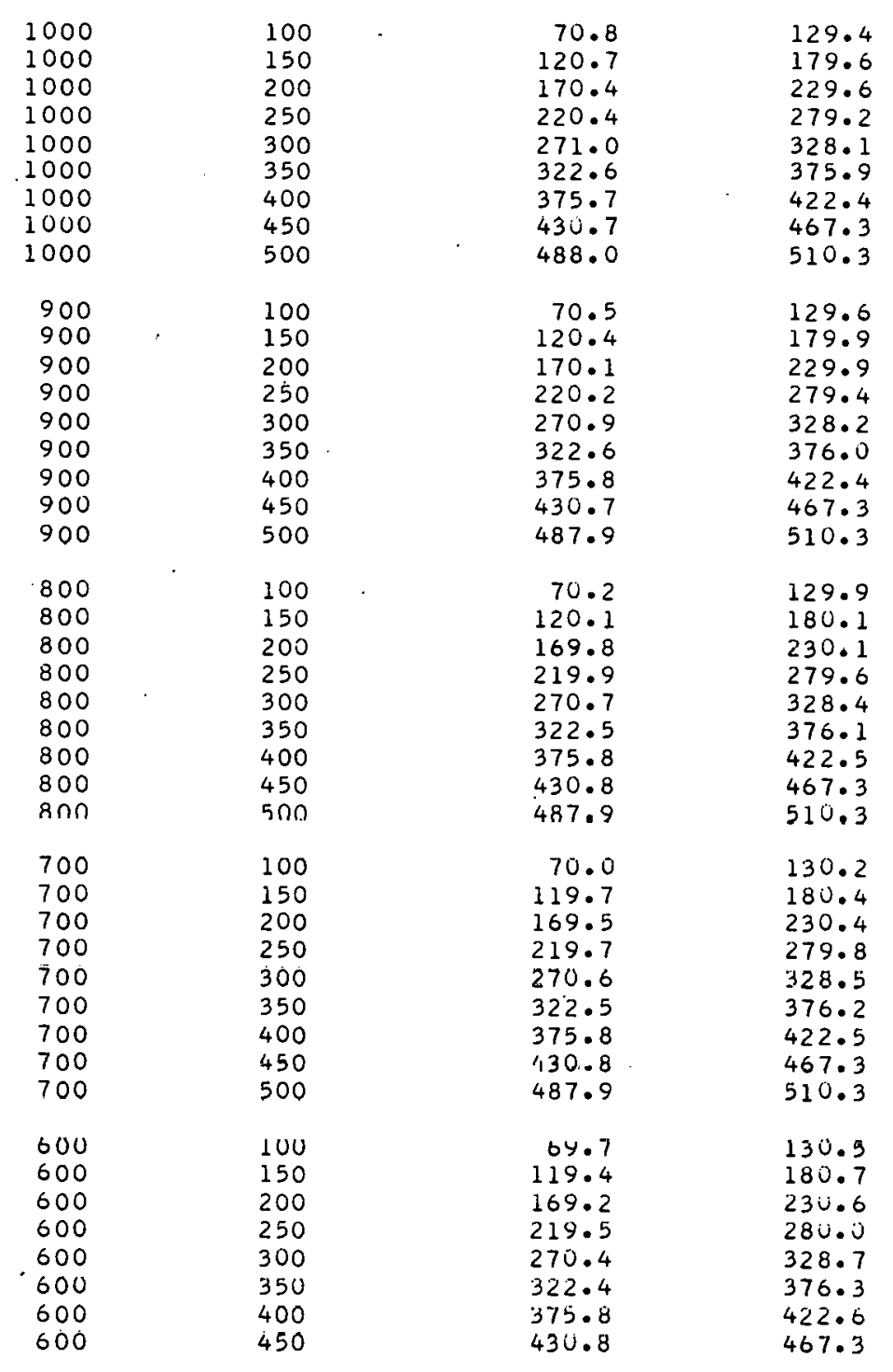

("ONT INUER) 


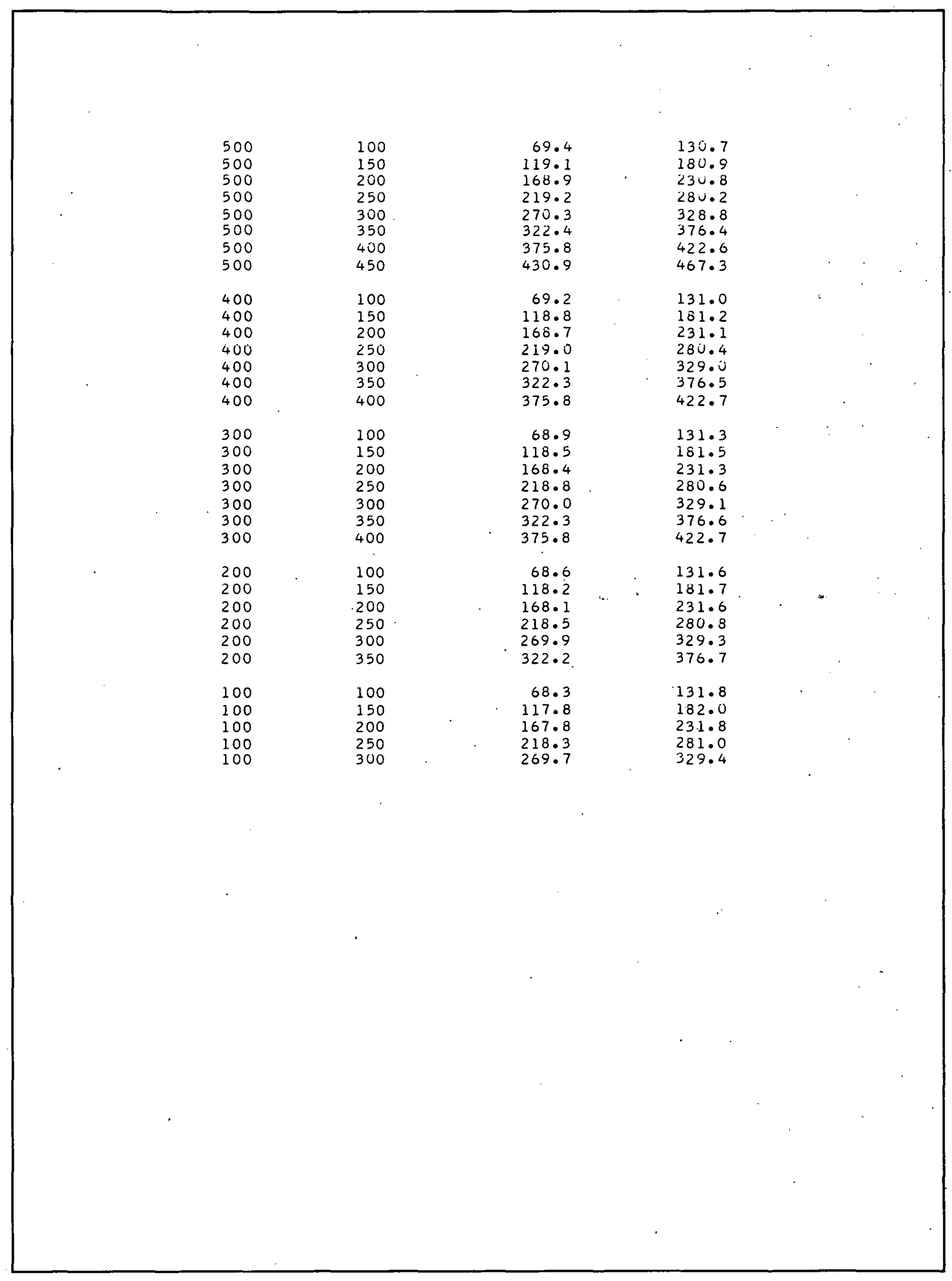


HEAT TRANSFER COEFFICIENT

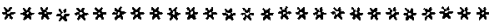

HT TRANSFER COEFF $=(C)(F)\left(G / 10^{6}\right)^{0.8}(D E)^{-0.2}$

WHERE*

$C=$ equATION COEFFICIENT. UI9,.023,. U3U, ETC.

$G=$ MASS VELOCITY - POUNOS/HOUR-SQUARE FT

DE = HYDRAULIIC DIAMETER OF CHANNEL - FT

$F=25391.0+64.78 \mathrm{H}$

$=20281.7+135.5 \mathrm{H}-.10361 \mathrm{H}^{2}$

H GUO BTU/LB

H Gंग BTU/LO 
FAMILY OF CURVES REPRESENTING BULK BOILING PRESSURE DRUP DATA VERTICAL UP-FLOW AT 2 UUOO PSI IPHI ${ }^{2}$ '

CURVE FIT EGUATIONS

FOR MASS VELOCITY . 7 G $5.0110^{\circ}$,

FOR QUALITY

$0 \times .40$

$$
{ }_{\text {PHI }}^{2}=1+\frac{7(x)^{.75}}{\left(G / 10^{6}\right)^{1+X}}
$$

(CONT I NUED) 
FAMILY OF CURVES REPRESENTING BULK BOILING PRESSURE DROP OATA

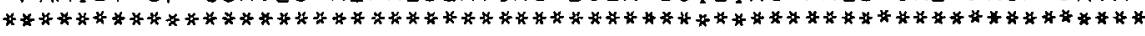

TABLE OF VALUES

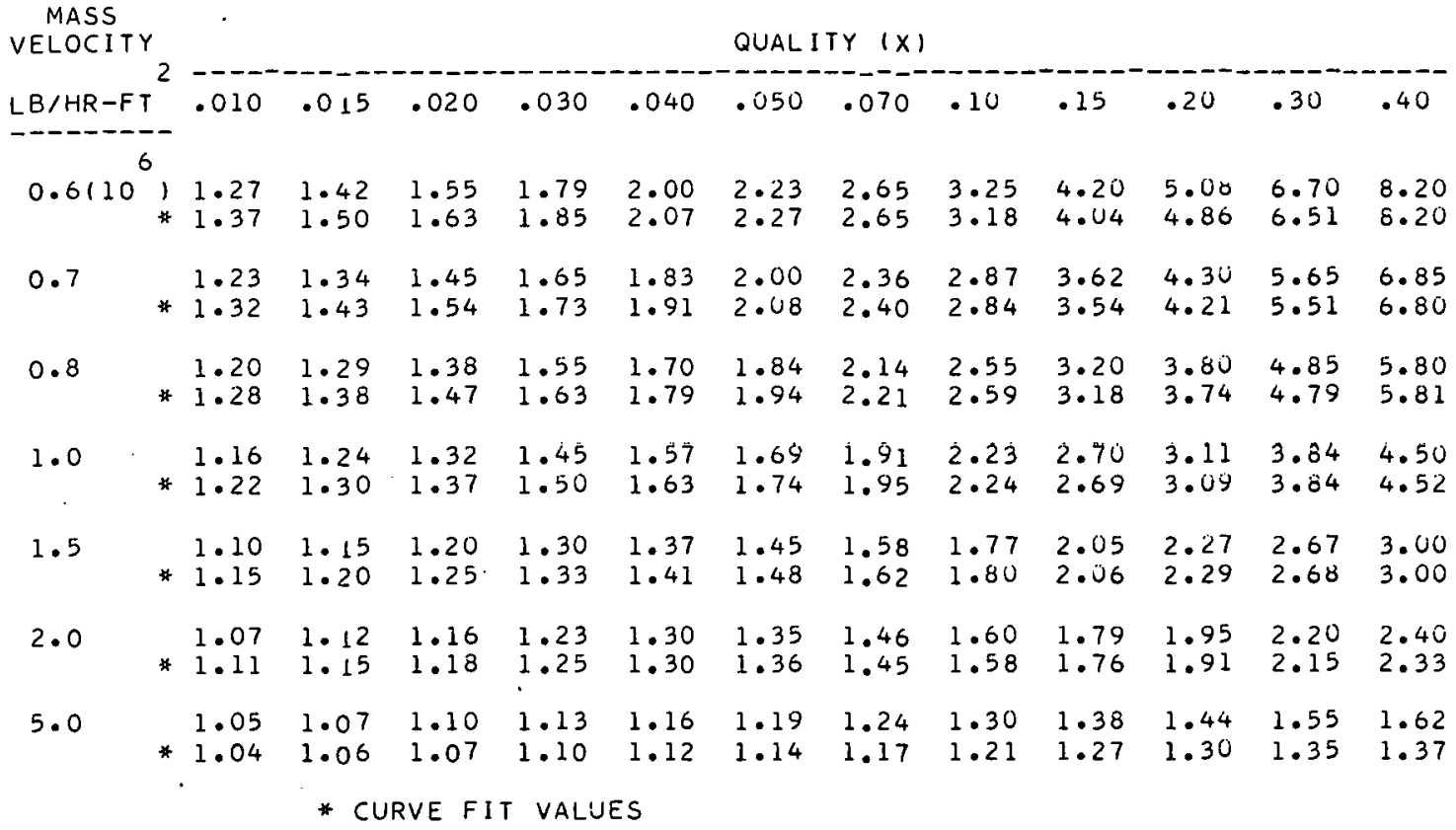

$\mathrm{REF}^{*} 2$ 


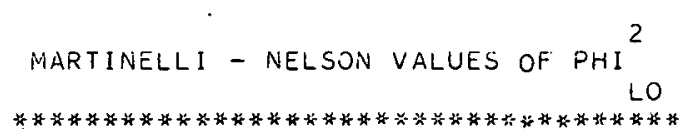

CURVE FIT EQUATIONS

FOR QUALITY $0 \times \quad \times 02$

$\mathrm{PHI}_{\mathrm{LO}}^{2}=1.0$

FOR QUALITY .02'X .20

$$
\begin{aligned}
& P H I^{2}=x^{1.9326-.2263 \times 1 J^{-3} P_{1}} \\
& \text { LO } 1.65 \times 10^{-3}+2.983 \times 10^{-5} P-2.528 \times 10^{-9} P^{2}+1.14 \times 10^{-11} P^{3}
\end{aligned}
$$

FOR QUALITY .20 X 1.0

$$
\begin{aligned}
& \mathrm{PHI}^{2}=\mathrm{x}^{\left(1.0205-.2053^{\circ} \times 10^{-3} \mathrm{P}\right)} \\
& \text { LO } 7.876 \times 10^{-4}+3.177 \times 10^{-5} P-6.728 \times 10^{-9} P^{2}+1.073 \times 10^{-11} P^{3} \\
& P=\text { PRESSURE - PSI }
\end{aligned}
$$

(LONTINUEU) 


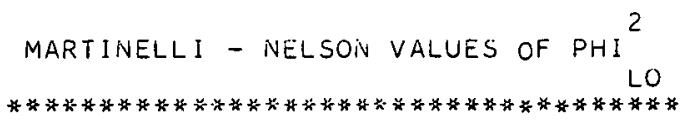

TABLE OF VALUES

\begin{tabular}{|c|c|c|c|c|c|c|c|c|c|c|c|c|}
\hline PRESSURE & & & & & & QUA & ITY $(x)$ & & & & & \\
\hline$\cdots-\cdots$ & .010 & .042 & .10 & .20 & .30 & .40 & .50 & .60 & .70 & .80 & .90 & 1.0 \\
\hline 100 & $\begin{array}{r}3.0 \\
* \quad 1.0\end{array}$ & $\begin{array}{l}12.0 \\
12.1\end{array}$ & $\begin{array}{l}26.5 \\
26.6\end{array}$ & $\begin{array}{l}51.5 \\
50.0\end{array}$ & $\begin{array}{l}82.0 \\
77.2\end{array}$ & $\begin{array}{l}111 . \\
102.9\end{array}$ & $\begin{array}{l}137 . \\
128.6\end{array}$ & $\begin{array}{l}167 . \\
154.3\end{array}$ & $\begin{array}{l}191 . \\
180^{\circ}\end{array}$ & $\begin{array}{l}211 . \\
205.0\end{array}$ & $\begin{array}{l}204 . \\
231.5\end{array}$ & $\begin{array}{l}153 . \\
257.2\end{array}$ \\
\hline 2.50 & $\begin{array}{r}2.6 \\
+\quad 1.0\end{array}$ & $\begin{array}{l}6.8 \\
6.8\end{array}$ & $\begin{array}{l}14.4 \\
14.6\end{array}$ & $\begin{array}{l}26.6 \\
\angle 8.7\end{array}$ & $\begin{array}{l}40.0 \\
37.3\end{array}$ & $\begin{array}{l}5 u .0 \\
4 \% .3\end{array}$ & $\begin{array}{l}62 \cdot 0 \\
81 \cdot 1\end{array}$ & $\begin{array}{l}73.0 \\
75.0\end{array}$ & $\begin{array}{l}83.0 \\
34.7\end{array}$ & $\begin{array}{l}89.0 \\
90.4\end{array}$ & $\begin{array}{r}38.5 \\
100.1\end{array}$ & $\begin{array}{r}65.9 \\
119.7\end{array}$ \\
\hline 500 & $\begin{array}{r}2.0 \\
* \quad 1.0\end{array}$ & $\begin{array}{l}4.3 \\
4.3\end{array}$ & $\begin{array}{l}8.6 \\
8.7\end{array}$ & $\begin{array}{l}15.4 \\
15.4\end{array}$ & $\begin{array}{l}22.3 \\
2 u \cdot 9\end{array}$ & $\begin{array}{l}27.9 \\
27.2\end{array}$ & $\begin{array}{l}33.7 \\
33.4\end{array}$ & $\begin{array}{l}39.5 \\
39.5\end{array}$ & $\begin{array}{l}44.5 \\
45.5\end{array}$ & $\begin{array}{l}48.0 \\
51.3\end{array}$ & $\begin{array}{l}48.0 \\
57.3\end{array}$ & $\begin{array}{l}34.0 \\
63.2\end{array}$ \\
\hline 750 & $\begin{array}{r}1.7 \\
* 1.0\end{array}$ & $\begin{array}{l}3.2 \\
3.2\end{array}$ & $\begin{array}{l}6.3 \\
6.3\end{array}$ & $\begin{array}{l}10.6 \\
10.7\end{array}$ & $\begin{array}{l}15.1 \\
14.5\end{array}$ & $\begin{array}{l}19.1 \\
18.7\end{array}$ & $\begin{array}{l}22.9 \\
22.6\end{array}$ & $\begin{array}{l}26.9 \\
26.5\end{array}$ & $\begin{array}{l}3 v .0 \\
3.0 .3\end{array}$ & $\begin{array}{l}32.9 \\
34.1\end{array}$ & $\begin{array}{l}32.8 \\
37.7\end{array}$ & $\begin{array}{l}22.4 \\
41.3\end{array}$ \\
\hline 1000 & $\begin{array}{r}1.5 \\
* \quad 1.0\end{array}$ & $\begin{array}{l}2.6 \\
2.6\end{array}$ & $\begin{array}{l}4.9 \\
4.9\end{array}$ & $\begin{array}{l}7.9 \\
7.9\end{array}$ & $\begin{array}{l}11.0 \\
1 C .8\end{array}$ & $\begin{array}{l}14.1 \\
13.7\end{array}$ & $\begin{array}{l}16 \cdot 8 \\
16 \cdot 4\end{array}$ & $\begin{array}{l}19.8 \\
19.1\end{array}$ & $\begin{array}{l}22.0 \\
21.6\end{array}$ & $\begin{array}{l}24 \cdot u \\
24 \cdot 1\end{array}$ & $\begin{array}{l}23.0 \\
26.6\end{array}$ & $\begin{array}{l}16.2 \\
28.9\end{array}$ \\
\hline 1250 & $\begin{array}{r}1.3 \\
* 1.0\end{array}$ & $\begin{array}{l}2.2 \\
2.2\end{array}$ & $\begin{array}{l}4.0 \\
3.9\end{array}$ & $\begin{array}{l}6.2 \\
5.1\end{array}$ & $\begin{array}{l}8 \cdot 3 \\
8 \cdot 3\end{array}$ & $\begin{array}{l}10.6 \\
10.4\end{array}$ & $\begin{array}{l}12 \cdot 6 \\
12 \cdot 3\end{array}$ & $\begin{array}{l}14.6 \\
14.2\end{array}$ & $\begin{array}{l}16.1 \\
15.9\end{array}$ & $\begin{array}{l}17.0 \\
17.0\end{array}$ & $\begin{array}{l}17.5 \\
19.2\end{array}$ & $\begin{array}{l}12.4 \\
20.9\end{array}$ \\
\hline 1500 & $\begin{array}{r}1.2 \\
* \quad 1.0\end{array}$ & $\begin{array}{l}2.0 \\
1.9\end{array}$ & $\begin{array}{l}3.3 \\
3.2\end{array}$ & $\begin{array}{l}4 \cdot 9 \\
4.9\end{array}$ & $\begin{array}{l}6.6 \\
6.5\end{array}$ & $\begin{array}{l}8.2 \\
8.0\end{array}$ & $\begin{array}{l}9.5 \\
9.4\end{array}$ & $\begin{array}{l}10.8 \\
10.7\end{array}$ & $\begin{array}{l}11.9 \\
11.9\end{array}$ & $\begin{array}{l}13.0 \\
13.1\end{array}$ & $\begin{array}{l}13.0 \\
14.0\end{array}$ & $\begin{array}{r}9.7 \\
13.4\end{array}$ \\
\hline 1750 & $\begin{array}{r}1.2 \\
* \quad 1.0\end{array}$ & $\begin{array}{l}1.7 \\
1.7\end{array}$ & $\begin{array}{l}2.7 \\
2.7\end{array}$ & $\begin{array}{l}3.9 \\
3.9\end{array}$ & $\begin{array}{l}5.0 \\
5.2\end{array}$ & $\begin{array}{l}6.2 \\
6.3\end{array}$ & $\begin{array}{l}7 \cdot 2 \\
7 \cdot 3\end{array}$ & $\begin{array}{l}8 \cdot 1 \\
8 \cdot 2\end{array}$ & $\begin{array}{l}9.0 \\
9.1\end{array}$ & $\begin{array}{l}9.7 \\
9.9\end{array}$ & $\begin{array}{r}9.7 \\
10.7\end{array}$ & $\begin{array}{r}7.8 \\
11.5\end{array}$ \\
\hline 2000 & $\begin{array}{r}1.1 \\
* \quad 1.0\end{array}$ & $\begin{array}{l}1.5 \\
1.5\end{array}$ & $\begin{array}{l}2.3 \\
2.3\end{array}$ & $\begin{array}{l}3 \cdot 2 \\
3 \cdot 2\end{array}$ & $\begin{array}{l}4.0 \\
4.2\end{array}$ & $\begin{array}{l}4.7 \\
5.0\end{array}$ & $\begin{array}{l}5 \cdot 5 \\
5 \cdot 7\end{array}$ & $\begin{array}{l}6.3 \\
6.4\end{array}$ & $\begin{array}{l}7.0 \\
7.6\end{array}$ & $\begin{array}{l}7.6 \\
7.6\end{array}$ & $\begin{array}{l}7.7 \\
8.1\end{array}$ & $\begin{array}{l}6.3 \\
8.7\end{array}$ \\
\hline
\end{tabular}

REF* 2 
MARTINELLI VALUES OF VOID FRACTIONS (RG) INCLUDING MODIFICATIONS

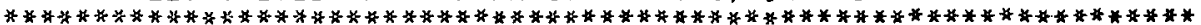

CURVE FIT EQUATIONS

$$
\text { VOID FRACTION }(R G)=A_{0}+A_{1} x+A_{2} x^{2}+A_{3} x^{3}
$$

WHERE*

FOR QUALITY $0 \times .01$

$$
\begin{aligned}
& A_{0}=A_{1}=A_{2}=A_{3}=0 \\
& \text { (STDY3 PROGRAM USES FOG FLOW MODEL) } \\
& \text { (FOR DENSITY IN THIS RANGE }
\end{aligned}
$$

FOR QUALITY .0I X .10

$$
\begin{aligned}
& A_{0}=+.5973-1.275 \times 10^{-3} P+9.019 \times 10^{-7} P^{2}-2.065 \times 10^{-10} P^{3} \\
& A_{1}=+4.746+4.156 \times 10^{-2} P-4.011 \times 10^{-5} P^{2}+9.867 \times 10^{-9} P^{3} . \\
& A_{2}=-31.27-.5599 P+5.580 \times 10^{-4} P^{2}-1.378 \times 10^{-7} P^{3} . \\
& A_{3}=+89.07+2.408 P-2.367 \times 10^{-3} P^{2}+5.694 \times 10^{-7} P^{3} .
\end{aligned}
$$

FOR QUALITY $\cdot 10 \times \cdot 90$

$$
\begin{gathered}
A_{0}=+.7847-3.900 \times 10^{-4} P+1.145 \times 10^{-7} P^{2}-2.771 \times 10^{-11} P^{3} \\
A_{1}=+.7707+9.619 \times 10^{-4} P-2.010 \times 10^{-7} P^{2}+2.012 \times 10^{-11} P^{3} \\
A_{2}=-1.060-1.194 \times 10^{-3} P+2.618 \times 10^{-7} P^{2}-6.893 \times 10^{-12} P^{3} \\
A_{3}=+.5157+6.506 \times 10^{-4} P-1.938 \times 10^{-7} P^{2}+1.925 \times 10^{-11} \mathrm{~F}^{3} \\
\text {. P }=\text { PRESSURE - PSI }
\end{gathered}
$$

FOR QUALITY .90 $\times 1.0$

$$
A=1.0 \quad A_{1}=A_{2}=A_{3}=0 \begin{aligned}
& \text { (STDY } 3 \text { PROGRAM USES FOG FLOW MODEL) } \\
& \text { (FOR DENSITY IN THIS RANGE }
\end{aligned}
$$

(CONT INUED) 
MARTINELLI VALUES OF VOID FRACTIONS (RG) INCLUDING MODIFICATIONS

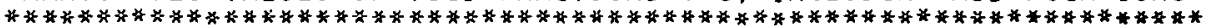

TABLE OF VALUES

\begin{tabular}{|c|c|c|c|c|c|c|c|c|c|c|c|c|}
\hline \multirow{2}{*}{\multicolumn{2}{|c|}{$\begin{array}{c}\text { PRESSURE } \\
\text { PSI }\end{array}$}} & \multicolumn{11}{|c|}{ QUALITY $(X)$} \\
\hline & & .010 & .042 & .10 & .20 & .30 & .40 & .50 & .60 & .70 & $.8 j$ & .90 \\
\hline 100 & * & $\begin{array}{l}.565 \\
.556\end{array}$ & $\begin{array}{r}.717 \\
.714\end{array}$ & $\begin{array}{r}.823 \\
.818\end{array}$ & $\begin{array}{l}.887 \\
.877\end{array}$ & $\begin{array}{r}.919 \\
.916\end{array}$ & $\begin{array}{r}.939 \\
.942\end{array}$ & $\begin{array}{r}.955 \\
.957\end{array}$ & $\begin{array}{r}.968 \\
.967\end{array}$ & $\begin{array}{r}.977 \\
.974\end{array}$ & $\begin{array}{r}.986 \\
.982\end{array}$ & $\begin{array}{r}.991 \\
.994\end{array}$ \\
\hline 250 & $*$ & $\begin{array}{r}.435 \\
.446\end{array}$ & $\begin{array}{l}.656 \\
.665\end{array}$ & $\begin{array}{l}.770 \\
.777\end{array}$ & $\begin{array}{r}.849 \\
.845\end{array}$ & $\begin{array}{l}.890 \\
.891\end{array}$ & $\begin{array}{r}.914 \\
.921\end{array}$ & $\begin{array}{r}.938 \\
.941\end{array}$ & $\begin{array}{r}.953 \\
.954\end{array}$ & $\begin{array}{r}.966 \\
.964\end{array}$ & $\begin{array}{l}.977 \\
.975\end{array}$ & $\begin{array}{r}.990 \\
.992\end{array}$ \\
\hline 500 & * & $\begin{array}{l}.302 \\
.309\end{array}$ & $\begin{array}{l}.595 \\
.586\end{array}$ & $\begin{array}{r}.715 \\
.716\end{array}$ & $\begin{array}{r}.808 \\
.798\end{array}$ & $\begin{array}{r}.854 \\
.854\end{array}$ & $\begin{array}{l}.807 \\
.893\end{array}$ & $\begin{array}{r}.914 \\
.918\end{array}$ & $\begin{array}{r}.934 \\
.936\end{array}$ & $\begin{array}{r}.952 \\
.950\end{array}$ & $\begin{array}{r}.968 \\
.966\end{array}$ & $\begin{array}{r}.985 \\
.988\end{array}$ \\
\hline 750 & $*$ & $\begin{array}{r}.223 \\
.218\end{array}$ & $\begin{array}{l}.513 \\
.512\end{array}$ & $\begin{array}{r}.662 \\
.062\end{array}$ & $\begin{array}{l}.758 \\
.757\end{array}$ & $\begin{array}{r}.824 \\
.823\end{array}$ & $\begin{array}{r}.864 \\
.867\end{array}$ & $\begin{array}{r}.895 \\
.849\end{array}$ & $\begin{array}{l}.921 \\
.920\end{array}$ & $\begin{array}{r}.942 \\
.938\end{array}$ & $\begin{array}{l}.962 \\
.4588\end{array}$ & $\begin{array}{r}.982 \\
.485\end{array}$ \\
\hline 1000 & * & $\begin{array}{l}.170 \\
.162\end{array}$ & $\begin{array}{r}.440 \\
.443\end{array}$ & $\begin{array}{l}.617 \\
.614\end{array}$ & $\begin{array}{l}.729 \\
.720\end{array}$ & $\begin{array}{r}.797 \\
.794\end{array}$ & $\begin{array}{r}.843 \\
.846\end{array}$ & $\begin{array}{r}.878 \\
.882\end{array}$ & $\begin{array}{r}.908 \\
.907\end{array}$ & $\begin{array}{r}.931 \\
.928\end{array}$ & $\begin{array}{r}.956 \\
.951\end{array}$ & $\begin{array}{r}.978 \\
.982\end{array}$ \\
\hline 1250 & * & $\begin{array}{l}.130 \\
.130\end{array}$ & $\begin{array}{r}.375 \\
.379\end{array}$ & $\begin{array}{r}.569 \\
.568\end{array}$ & $\begin{array}{r}.690 \\
.684\end{array}$ & $\begin{array}{l}.768 \\
.766\end{array}$ & $\begin{array}{l}.820 \\
.824\end{array}$ & $\begin{array}{r}.862 \\
.865\end{array}$ & $\begin{array}{r}.894 \\
.894\end{array}$ & $\begin{array}{r}.922 \\
.919\end{array}$ & $\begin{array}{r}.950 \\
.945\end{array}$ & $\begin{array}{r}.976 \\
.979\end{array}$ \\
\hline 1500 & * & $\begin{array}{l}.106- \\
.111\end{array}$ & $\begin{array}{r}.324 \\
.323\end{array}$ & $\begin{array}{l}.514 \\
.521\end{array}$ & $\begin{array}{l}.659 \\
.647\end{array}$ & $\begin{array}{l}.739 \\
.737\end{array}$ & $\begin{array}{r}.793 \\
.802\end{array}$ & $\begin{array}{r}.843 \\
.847\end{array}$ & $\begin{array}{r}.879 \\
.881\end{array}$ & $\begin{array}{r}.912 \\
.909\end{array}$ & $\begin{array}{r}.942 \\
.938\end{array}$ & $\begin{array}{r}.972 \\
.976\end{array}$ \\
\hline 1750 & \# & $\begin{array}{l}.086 \\
.093\end{array}$ & $\begin{array}{r}.270 \\
.273\end{array}$ & $\begin{array}{r}.469 \\
.472\end{array}$ & $\begin{array}{r}.621 \\
.608\end{array}$ & $\begin{array}{r}.706 \\
.705\end{array}$ & $\begin{array}{l}.767 \\
.776\end{array}$ & $\begin{array}{r}.822 \\
.827\end{array}$ & $\begin{array}{r}.864 \\
.865\end{array}$ & $\begin{array}{r}.901 \\
.397\end{array}$ & $\begin{array}{r}.936 \\
.931\end{array}$ & $\begin{array}{r}.969 \\
.973\end{array}$ \\
\hline 2000 & * & $\begin{array}{r}.068 \\
.064\end{array}$ & $\begin{array}{l}.230 \\
.232\end{array}$ & $\begin{array}{r}.415 \\
.417\end{array}$ & $\begin{array}{r}.581 \\
.563\end{array}$ & $\begin{array}{r}.670 \\
.668\end{array}$ & $\begin{array}{r}.736 \\
.745\end{array}$ & $\begin{array}{r}.796 \\
.802\end{array}$ & $\begin{array}{r}.848 \\
.846\end{array}$ & $\begin{array}{r}.890 \\
.884\end{array}$ & $\begin{array}{l}.92 n \\
.923\end{array}$ & $\begin{array}{l}.965 \\
.970\end{array}$ \\
\hline
\end{tabular}

* CURVE fit VAlues

REF* 2 